\title{
The Effect of Feed Manufacture Techniques on Pathogen Reduction and Feed Nutrient Value
}

Timothy Paul Boltz

West Virigina University, tpb0015@mix.wvu.edu

Follow this and additional works at: https://researchrepository.wvu.edu/etd

Part of the Agriculture Commons, and the Poultry or Avian Science Commons

\section{Recommended Citation}

Boltz, Timothy Paul, "The Effect of Feed Manufacture Techniques on Pathogen Reduction and Feed Nutrient Value" (2019). Graduate Theses, Dissertations, and Problem Reports. 3880.

https://researchrepository.wvu.edu/etd/3880

This Thesis is protected by copyright and/or related rights. It has been brought to you by the The Research Repository @ WVU with permission from the rights-holder(s). You are free to use this Thesis in any way that is permitted by the copyright and related rights legislation that applies to your use. For other uses you must obtain permission from the rights-holder(s) directly, unless additional rights are indicated by a Creative Commons license in the record and/ or on the work itself. This Thesis has been accepted for inclusion in WVU Graduate Theses, Dissertations, and Problem Reports collection by an authorized administrator of The Research Repository @ WVU. For more information, please contact researchrepository@mail.wvu.edu. 
The Effect of Feed Manufacture Techniques on Pathogen Reduction and Feed Nutrient Value

Timothy P. Boltz

Thesis submitted

to the Davis College of Agriculture, Natural Resources, and Design

at West Virginia University

in partial fulfillment of the requirements for the degree of

Master of Science

In

Nutrition and Food Science

Joseph S. Moritz, Ph.D., Chair

Jacek Jaczynski, Ph.D.

Cangliang Shen, Ph.D.

Division of Animal and Nutritional Sciences

Morgantown, West Virginia

2019

Keywords: Salmonella, Conditioning Time, Conditioning Temperature, Hygieniser, Feed Manufacture

Copyright 2019 Timothy Paul Boltz 


\section{ABSTRACT \\ The Effect of Feed Manufacture Techniques on Pathogen Reduction and Feed Nutrient Value}

\section{Timothy P. Boltz}

Experiments were conducted to evaluate how differing feed manufacture techniques, such as varying conditioning times and new equipment, can affect pathogen mitigation, feed manufacture metrics, amino acid digestibility, and enzyme recovery in feed. Feed hygienics are of increasing importance in providing safe feed to animals, and ultimately safe food for consumers. Salmonella has been identified as a major microbial hazard in animal feed that has been linked to animal and human illness. In chapter 2, the effects of standard pelleting and more thermally aggressive techniques were utilized to determine pathogen mitigation potential. Use of antibiotics has decreased in recent years due to policies and practices of poultry production, increasing opportunities for potential pathogens in feed to affect poultry and poultry products. More thermally aggressive pelleting decreased pellet mill motor load $(\mathrm{P}=0.02)$, increased hot pellet temperature $(\mathrm{P}=0.02)$, and tended to increase pellet durability $(\mathrm{P}=0.07)$. E. faecium ATCC 8459 , as a Salmonella surrogate colonies were reduced with standard pelleting relative to inoculated mash and reduced further with more thermally aggressive pelleting $(\mathrm{P}<0.05)$.

Standard pelleting and more thermally aggressive pelleting resulted in a 3 and 4-log reduction in E. faecium ATCC 8459 colonies respectively, relative to inoculated mash. In chapter 3 , varying steam conditioning temperature and conditioning time were utilized to examine the how these interacted to affect pellet mill motor load, pellet quality, digestible amino acid concentration, and enzyme recovery. Corn and soybean meal based diets that included DDGS and meat and bone meal were conditioned at either $76^{\circ} \mathrm{C}, 82^{\circ} \mathrm{C}$, or $88^{\circ} \mathrm{C}$ with conditioning times of either 30 or 60 seconds. Conditioning temperature and time interacted to affect pellet mill motor load $(\mathrm{P}<0.05)$. Motor load decreased for 30 second conditioning compared to 60 second conditioning when diets were subjected to 76 and $82^{\circ} \mathrm{C}$, but motor load was similar among conditioning times at $88^{\circ} \mathrm{C}$. This interaction was likely due to the result of lower feed volume in the conditioner as per 30 second conditioning obtaining greater moisture condensation and lubrication at lower conditioning temperatures. Pellet quality increased with increased conditioning temperature $(\mathrm{P}<0.05)$, likely associated with greater starch gelatinization and protein gelation. Lysozyme activity decreased when conditioned at $88^{\circ} \mathrm{C}(\mathrm{P}<0.05)$, but was not affected by retention time. Conditioning temperature and time interacted to affect digestible amino acid concentrations of methionine, lysine, threonine, alanine, aspartic acid, glutamic acid, isoleucine, leucine, proline, and valine $(\mathrm{P}<0.05)$. Increased conditioning temperatures at 30 seconds increased digestible amino acid concentrations. Similarly, diets conditioned at 60 seconds increased digestible amino acid concentration between 76 and $82^{\circ} \mathrm{C}$. However, the digestible amino acid concentration decreased when diets were conditioned at 60 seconds and $88^{\circ} \mathrm{C}$. Perhaps negative effects on digestibility of trypsin inhibitor complexes and ingredient aleurone layers were decreased with increasing temperatures; however, the 60 second $88^{\circ} \mathrm{C}$ treatment may have been too thermally aggressive and rendered the proteins indigestible. 


\section{Acknowledgements}

I would like to take the time to thank several people, that without their support this degree would not be possible. I would first like to thank my major professor Dr. Joe Moritz. Without the support and guidance, he provided me over the last two years I would not be where I am today and will be forever grateful. Next, I would like to thank the other members of my committee, Dr. Jacek Jaczynski and Dr. Cangliang Shen for their support and guidance through my research and graduate courses. I would also like to acknowledge and thank my lab mates: Victoria Ayres, Kari Harding, Talman Hylton, Angela Lamp, Niles Ridgeway, and the undergraduate students.

Without their help, none of this would be possible. Lastly, I would like to thank my parents Paul and Kathy. Their support and encouragement has driven my efforts in education and allowed me to reach this milestone in my life. 


\section{TABLE OF CONTENTS}

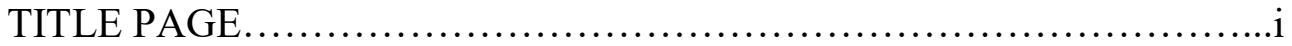

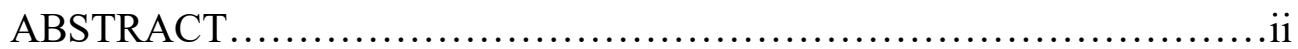

ACKNOWLEDGMENTS..............................................ii

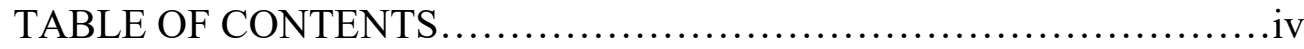

LIST OF TABLES....................................................... vi

ABBREVIATION KEY ...............................................

\section{CHAPTER ONE}

LITERATURE REVIEW.............................................

Feed Manufacture .......................................................

Grinding, Mixing, and Pelleting.......................................

Steam Conditioning....................................................

Pellet Quality .............................................................

Salmonella in Feed.................................................. 6

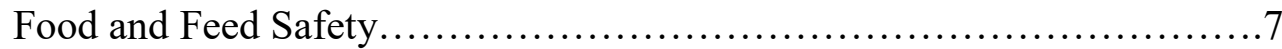

Salmonella Control.................................................... 8

Salmonella Reduction.................................................... 9

Salmonella Mitigation...................................................10

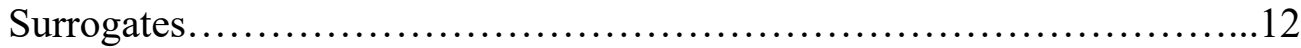

Conclusions/Recommendations .....................................13

Future Research..................................................13

References.............................................................

\section{CHAPTER TWO}

THE EFFECT OF STANDARD PELLETING AND MORE THERMALLY AGGRESSIVE PELLETING UTLIZING A HYGIENISER ON FEED MANUFACTURE AND REDUCTION OF ENTEROCOCCUS FAECIUM, A SALMONELLA SURROGATE 


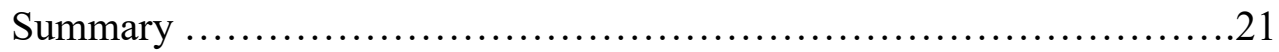

Description of Problem.................................................22

Materials and Methods..............................................24

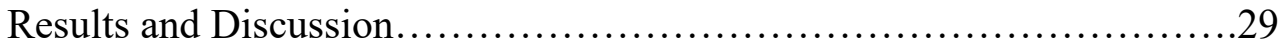

Conclusions and Applications............................................. 31

References and Notes................................................ 32

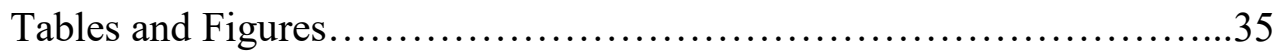

\section{CHAPTER THREE}

THE EFFECT OF VARYING STEAM CONDITIONING TEMPERATURE AND TIME ON PELLET MANUFACTURE VARIABLES, DIGESTIBLE AMINO ACID CONCENTRATION, AND FEED ENZYME RECOVERY

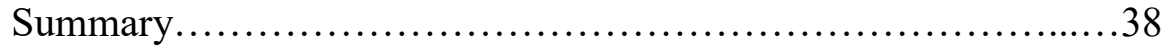

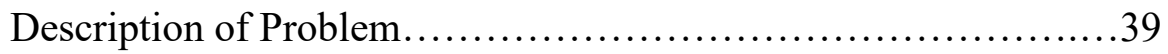

Materials and Methods.......................................... 40

Results and Discussion...........................................43

Conclusions and Applications.......................................45

References and Notes...........................................46

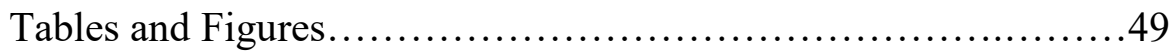

CURRICULUM VITAE..........................................54 


\section{LIST OF TABLES}

\section{CHAPTER TWO}

Table 1. Dietary composition and calculated nutrients of the basal diet used for

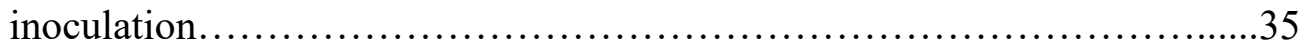

Table 2. Pelleting Technique and Hygieniser Use on Feed Manufacturing Metrics and $E$. faecium 8459 mitigation..... 36

\section{CHAPTER THREE}

Table 1. Dietary composition and calculated nutrients of the basal diet.......49

Table 2. Effects of varying conditioning temperature and conditioning time on feed manufacture variables and pellet quality .............................50

Table 3. The effects of conditioning temperature and conditioning time on Digestible Amino Acid Concentration..........................................51

Figure 1. Interaction of Digestible Lysine Concentration..................52

Figure 2. Interaction of Digestible Methionine Concentration..............55

Figure 3. Interaction of Digestible Threonine Concentration..............53 


\section{ABBREVIATION KEY}

\section{Chapter 1}

1. Dried Distiller's Grains with Solubles - DDGS

2. Mixer added fat $-\mathrm{MAF}$

3. Hazard Analysis and Risk-Based Preventive Controls - HARPC

4. Veterinary Feed Directive - VFD

5. Species - Spp.

6. American Type Culture Collection - ATCC

7. Agriculture Research Service Culture Collection - NRRL

Chapter 2

1. Food Safety Modernization Act - FSMA

2. Horse Power - HP

3. Metric Ton - MT

4. Programmable Logic Control - PLC

5. New Holman Pellet Tester - NHPT

6. Brain-heart infusion broth $-\mathrm{BHI}$

7. Tryptic soy broth - TSB

8. Phosphate Buffered Saline - PBS

9. Colony Forming Unit $-\mathrm{CFU}$

10. Generalized Linear Model - GLM

11. Statistical Analysis System - SAS

Chapter 3

1. Dried Distiller's Grains with Solubles - DDGS

2. Trypsin Inhibitor Unit - TIU

3. Horse Power - HP

4. Metric Ton-MT

5. Programmable Logic Control - PLC

6. New Holman Pellet Tester - NHPT

7. Single Comb White Leghorn - SCWL

8. Amino Acid - AA

9. Generalized Linear Model - GLM

10. Statistical Analysis System - SAS

11. Lysine - Lys

12. Methionine - Met

13. Threonine $-\mathrm{Thr}$ 


\section{CHAPTER ONE \\ LITERATURE REVIEW}

\section{Feed Manufacture}

Feed manufacture is a crucial step in the broiler production system. In 2016, it was estimated on a global scale that one billion tons of feed were produced, with around $45 \%$ going towards poultry [1]. Feed costs are associated with $60-65 \%$ of total production costs, along with a large initial capital investment [2-3]. Pelleting feed was introduced to Europe around 1920, and then came to the United States around 1930 [4]. Pelleting decreases energy expenditure of the animal, spillage, ingredient segregation, selective feeding, and pathogens that may be associated with ingredients [5-6]. All of these factors come together to produce a feed that permits animals to have increased daily gain and decreased feed conversion relative to mash diets [3,7]. Since the late 20th century, animals have been selectively bred for production traits, resulting in improved breeds with genetically superior animals [5]. Feed manufacturers now have the responsibility to provide feed for these animals that allows for these genetic improvements to be realized.

\section{Grinding, Mixing, and Pelleting}

Before pellets can be produced, ingredients must first be ground and mixed together. Grinding results in particle reduction, which is needed to allow the feed to have improved binding ability with other ingredients in the diet to form a pellet [7]. Grinding is usually done for cereals such as corn before being mixed. The smaller particles also create more surface area for digestion to occur within the gastrointestinal tract of the animal. This especially helps poultry, as these animals have short digestive tracts and digestibility of feed must be high [8]. Particle reduction can be accomplished using machinery such as hammer and roller mills. Mixing is critical and essential to ensure that all the feed ingredients are thoroughly mixed and are ready for the pelleting process [5]. After all ingredients are ground and mixed, the mixture can then be 
pelleted. Pellets are formed by agglomerating smaller feed particles with the help of machinal pressure, moisture, and heat from steam to heat the larger particles [8].

Pellets are easier to store and handle than a mash feed, which is beneficial to an operation that needs to feed tens of thousands of animals on a daily basis. Pellets flow more efficiency through conveying equipment and have superior discharging behavior from silos than mash feed [9-11]. Pellets also have greater bulk density than mashed feed, which allows for more pelleted feed to be hauled in a load which can potentially reduce costs on trucking [7]. Quality of pellets can be measured on the hardness and durability of the pellet, which these measures can be used to evaluate the effects of diet formulation, conditioning, expander treatment, pellet binders, and die selection [12].

\section{Steam Conditioning}

Steam conditioning temperature is a manipulable thermo-mechanical processing variable that influences the quality of feed that will be produced, with common temperatures of $76^{\circ} \mathrm{C}$ to $93^{\circ} \mathrm{C}$ commonly being used [2]. Utilizing higher temperatures have been shown to result in high quality pellets, which is desired in the poultry industry, as well as possibly decreasing pathogen population in the feed $[2,13]$. Alternatively, these higher temperatures can negatively affect the nutrients of feed which has been shown when utilizing $70^{\circ} \mathrm{C}$ has shown to increase broiler performance, whereas at $90^{\circ} \mathrm{C}$ performance was observed to be decreased [14]. The observed decrease could be associated with lowered nutrient availability in the feed due to the high temperature not allowing the birds to get all required nutrients to obtain their maximum genetic potential.

Heat is commonly applied to feed as it can aid in destruction of pathogens and anti-nutritive factors, such as trypsin inhibitors that can be found in soybean meal [2]. This makes steam 
conditioning the most important step in the feed manufacture process to reduce potential pathogens associated with the feed [15]. Though the effectiveness of this step can be reduced if there is equipment malfunctions, uneven heating or incomplete mixing [16].

Temperatures used to condition the feed can have an impact on the amino acid and vitamin availability as well as enzyme activity of the final feed. Conditioning temperatures of $85^{\circ} \mathrm{C}$ and $96^{\circ} \mathrm{C}$ have been shown to significantly reduce digestibility of methionine, isoleucine, and proline when compared to diets conditioned at $74^{\circ} \mathrm{C}$ [17]. Boney and Moritz later found that at $91{ }^{\circ} \mathrm{C}$ leucine, valine, isoleucine, alanine, and aspartic acid digestibility decreased when compared to diets conditioned at $74^{\circ} \mathrm{C}$ and $82^{\circ} \mathrm{C}$ [18]. Vitamins are also susceptible to damage during steam conditioning as well, where Cutlip and colleagues found a $6.7 \%$ loss in vitamin $\mathrm{A}$ at $93^{\circ} \mathrm{C}$ [2]. Feed-born and exogenous enzymes can also lose activity due to certain temperatures denaturing the enzyme, which could cause deficiencies in the birds that are provided this feed [19-20]. Feed producers must consider that at too low of temperatures pathogen mitigation might not be as much as desired but, these temperatures could maintain nutrient availability of the feed that will ultimately get to the bird. Steam conditioning temperature not only can affect the nutrient availability and pathogen load of feed, but also has an important role in producing quality pellets.

\section{Pellet Quality}

Pellet quality is an important factor to consider when wanting to maximize animal performance, but is often considered poor in the commercial US industry [3]. It has been shown that one of the simplest way to improve pellet quality is to use higher steam conditioning temperatures, but this could have a negative impact on the final nutrient composition of the feed $[2,13,17]$. An increase of feed conversion by 2.4 percentage points resulted when broilers were fed a combination of $75 \%$ pellet and $25 \%$ fines when compared to being fed $25 \%$ pellet and $75 \%$ fines 
[21]. Modest improvements in pellet quality from $50 \%$ crumble/pellet to $70 \%$ may improve broiler performance and decreased feed conversation ratio by 3 points [22]. Commercial diets are commonly formulated on a least cost basis, which frequently include inexpensive by-products like meat and bone meal, which can negatively impact pellet quality and can potentially introduce pathogens to the feed $[3,23]$. Use of varying inclusions of non-by-product ingredients and using different sized pellet dies are other ways to improve pellet quality without having to use as extreme of condition temperatures.

Addition of certain ingredients can improve pellet quality, while certain inclusions of others can be detrimental to pellet quality. Dried distillers' grains with solubles (DDGS) and oat hulls are two examples of by-products that when added at certain amounts decrease pellet quality [3,24]. Inclusion of $2 \%$ and $4 \%$ oat hulls in a diet negatively affected the pellet quality when compared to no addition [3]. Where additions of $15 \%$ and 30\% DDGS in grower-phase yielded decreased pellet quality and increased amount of total fines and lower amount of intact pellets [25]. Inclusion of DDGS at $8 \%$ in grower diets and $16 \%$ in finisher diets have also shown to decrease pellet quality [26]. Wamsley and colleagues alternately demonstrated increasing DDGS in the diet tended to not affect pellet quality until the finisher phase, which contained $10 \%$ or $20 \%$ DDGS [27]. Diet formulation should be taken into consideration if pellet quality is desired to be improved, as addition of certain alternative ingredients have been shown to improve the quality of pellets produced.

Addition of protein and fibrous material pre-pelleting should be done [6]. Buchanan and Moritz found that adding fiber in the form of cellulose and protein in the form of soy protein isolate at 5\% improved pellet quality [3]. Buchanan and Moritz also found that pellet durability index and modified pellet durability index can be improved through small inclusions of protein 
(around $2 \%$ ) in the form of soybean meal and moisture (3-4\%) in the form of tap water [3].

Moritz also found that moisture can be added at the mixer to improve pellet quality [28].

The use of Spirulina algae has been shown to be a promising pellet binder due to the large amount of protein (76\%) associated with the algae. Using a corn-soy diet, it was demonstrated that going from $0 \%$ to $10 \%$ algae in the diet improved pellet quality by 31 -percentage points when the feed was conditioned at $74^{\circ} \mathrm{C}[18]$. When the same diets were pelleted at $91^{\circ} \mathrm{C}$ the difference was only 5-percentage points [18]. When pellet quality was tested using a new Holmen pellet tester, a 51-percentage point difference was seen for the $74^{\circ} \mathrm{C}$, while a 7 -percentage point difference was seen for the $91^{\circ} \mathrm{C}[18]$. Buchanan and colleagues found that research based diets that were pelleted utilizing a thick die and slow production rate resulted in higher pellet durability index and modified pellet durability index scores when compared to diets that were formulated on a least cost basis and pelleted using a thin die at a high production rate [23]. The research based diets were formulated to contain $3.87 \%$ more crude protein than the least cost formulated diets with additional moisture added [23]. These additions could explain why the research diet had improved pellet quality when compared to the commercial least cost diet. Addition of fat and oils, either pre-or post-pelleting can also have an impact on the quality of the final pellets.

Fat addition pre-and post-pelleting has been shown to both improve and decrease pellet quality, depending on the inclusion percentage. Low mixer added fat (MAF) (1\%) can be added pre-pelleting to a diet, and the remaining fat added post pelleting to improve pellet quality [29]. Increased amounts of MAF can prevent reduction of nutrient availability [30]. The fat could reduce the friction between the pellet die and mash feed, preserving some nutrients that may be loss to the frictional heat that is generated [30]. Addition of fat under 5.6\% and protein content around 20\% showed to not impact pellet quality negatively [21]. Addition of too much fat at the mixer can be 
detrimental though, where Wamsley and Moritz found inclusion of 3\% mixer added fat with a thicker die $(44.9 \mathrm{~mm})$, negatively impacted pellet quality [29]. Inclusion of $7.5 \%$ or greater oil in the diet has shown to have a negative impact on the pellet quality as well [21]. It should also be noted that fat and oil addition can possibly introduce pathogens to feed if added post pelleting as these ingredients do not undergo any pathogen reduction treatments [16]. Salmonella contamination of feed is a major concern for the feed industry and requires a great deal of management to control.

\section{Salmonella in Feed}

Salmonella spp. are major microbial hazards in animal feed and have been linked between infected feed and illness in both animals and humans [31]. Salmonella spp. are gram negative, facultative anaerobic, nonspore forming, rod shaped bacteria that have the potential to cause illness and death in humans and livestock [32]. Poultry can consume feed that is contaminated with Salmonella and not exhibit any clinical signs of the disease. Later these birds can contaminate processing facilities when being eviscerated, which can transfer Salmonella to the carcasses [33]. Salmonella is native to the gastrointestinal tract of livestock and is commonly found in nature in a variety of places, such as poultry feed and feces [34-37]. Most of these places in nature contain low moisture, so supplemental moisture is needed for reproduction, like in feed and the feed mill environment [31]. The water activity reported by Greco et al. for feed is 0.537 , which is lower than the optimal water activity for pathogenic bacteria to thrive in [38].

Numerous serotypes of Salmonella spp. have been isolated from feed mills, with Salmonella typhimurium and Salmonella enteritidis being sampled frequently [39]. Salmonella enterica being the leading cause of death and hospitalizations in the United States and Salmonella enterica serovar Kentucky being the leading serovar isolated from poultry and 
poultry products [40-41]. In Great Britian a study was conducted to test the different serovars sampled from various feed ingredients from 1987 to 2006. Mbandaka was sampled most frequently for soybean, Montevideo for meal and bone meal, and Schwarzemgrund for corn [42]. Government regulations have been put into place to aid the production of safe feed and ultimately safe food for consumers.

\section{Food and Feed Safety}

It has been estimated that every year in the United States approximately 48 million people get sick, 128,000 are hospitalized, and 3,000 die from food borne illness [43]. This means that 1 in 6 American will become ill annually from a food borne illness [43]. On January 4, 2011, the Food and Drug Administration (FDA) Food Safety Modernization Act (FSMA) was signed into effect by President Obama, which was passed by Congress to help address public food safety challenges. This new piece of regulation shifted the focus from reacting to food borne outbreaks to protection and prevention of outbreaks. This new legislation introduced mandated a comprehensive, science-based preventive controls in facilities. Facilities must conduct Hazard Analysis and Risk-Based Preventive Controls (HARPC) and establish science-based preventive control measures that reduce risk of contamination, whereas before programs like this were voluntary.

Another way that the FDA is trying to keep the food supply safe with is the Veterinary Feed Directive (VFD), which was signed into effect January 1, 2017 [44]. These are stricter federal rules that regulate how medically important medications, such as tetracycline and penicillin, are administered to animals in feed (require a VFD) and water (require a prescription). With proper administration of antibiotics to reduce the opportunity for resistance to develop and keep a supply of antibiotics when there are situations of true need to keep both humans and 
animals healthy. To aid in producing safe food control measures have to be in place to control possible Salmonella contamination.

\section{Salmonella Control}

Salmonella spp. are ubiquitous in nature and have superb survivability [35]. Because of this ability multiple tools for control should be utilized and control efforts should be a regular part of the feed manufacture process, which can be referred to as a multiple hurdle approach [45]. Three broad categories of Salmonella control principles for feed are recognized: 1. Efforts to prevent contamination, 2. Effort to reduce microbial multiplication, and 3. Plans to kill the pathogen [46]. Contaminated feed is the main vector of introduction, so it is prudent to assume all incoming feed is contaminated and should be handled as such [47]. The more handling that the feed is subjected to, the higher the chance of contamination to uncontaminated feed is, so handling should be kept to only when required [48].

Multiple practices can be implemented to help prevent contamination from occurring. Purchasing feed from suppliers that test ingredients is advised since this reduces the chance of bringing Salmonella into the production system [49]. Another area of significance to control is dust at receiving and during grinding to reduce the possibly of aerosol spread of Salmonella. Dust from raw material receiving is the largest source of dust emissions in the mill environment, but can also be produced by size reduction equipment like hammer mills and roll mills if not maintained properly [50-51]. Dust and caked material should not be at any location in the mill as these provide suitable substrate for Salmonella colonization [46]. Venting to the outside that is separate from the intake should be done as this may remove contaminated dust from the feed mill environment [46]. Filters installed on intakes can help to prevent any recontamination due to contaminated dust being up taken [46]. 
Preventing cross contamination between area of raw materials and finished pellets can be accomplished by implementing boot covers or other methods of disinfecting footwear between these areas and restricting the flow of equipment [31]. Reducing buildup of fats and oil in the feed mill decreases possible locations for Salmonella to survive and multiply, as these tend to protect Salmonella from outside stressors [52-54]. Controlling pests, such as rodents and wild birds, is another way to reduce the chance of having Salmonella contamination occur in the mill $[52,55]$. Jones and Ricke suggested that intake pits be cleaned with a neutral feed like corn containing organic acid as this can help to prevent any cross contamination that could happen in the feed mill [56]. Transport vehicles have been identified as another vector for this species of bacteria [57-58]. It is recommended to have trucks solely deliver raw ingredients and after each load be thoroughly cleaned to reduce any contamination to the next load [31]. Since this is not always practical, it is recommended to have drivers disclose the contents of the last three loads prior to delivery of raw ingredients [48].

\section{Salmonella Reduction}

Following control, there are practices that can be utilized to reduce Salmonella multiplication. The simplest way to reduce Salmonella is to control excess moisture in the mill environment [31]. Biofilms are a layer of microorganisms that created a colony that is difficult to eradicate and can form in niches that are not easily accessible [59]. Biofilms are common areas of cross-contamination where Salmonella can live and multiply. The lack of accessibility into the cooler for cleaning permits Salmonella to multiply and can cross-contaminate any feed that comes into contact with the biofilm. All feed facilities are unique in design, so the workers should be compelled to find any potential growth niches [59]. 
A common place that Salmonella can multiply rapidly in is the pellet cooling system. Hot pellets coming from the pellet mill release water vapor onto the cold surfaces in the cooler that condensate and trap dust in a moist area [61]. Contamination of new pellets entering the cooler can occur due to the colonization of Salmonella in the cooler [61]. Heating of the equipment to temperatures above the dew point of the air is the most effective way to prevent environments for contamination in the cooler [61]. Reduction of Salmonella is the final step to eliminate any Salmonella cells that survived the control and reduction practices.

\section{Salmonella Reduction}

Feed producers have options on how to aid in the mitigation of Salmonella in feeds that they are producing. These options can be thermal processing associated with pelleting, applying a chemical to the feed, or a combination of both which is the most effective way to mitigate Salmonella [31]. There are three factors associated with microbial lethality which are: 1. Temperature 2. Time of exposure at a certain temperature, and 3. Moisture [62]. It was speculated that at temperatures of approximately $71^{\circ} \mathrm{C}$ cells of pathogens start to be destroyed and can result in about a $10^{3} \mathrm{cfu} / 100 \mathrm{~g}$ reduction, with $79^{\circ} \mathrm{C}$ to $85^{\circ} \mathrm{C}$ the target temperatures for pathogen reduction [63-64]. Later it was demonstrated that pelleting at $80^{\circ} \mathrm{C}$ showed to reduce most Salmonella and other coliforms, while pelleting over $90^{\circ} \mathrm{C}$ was not a lethal temperature for spore forming bacteria [64-68]. Boney et al. found that mitigation potential was apparent with short term steam conditioning for 30 seconds was applied to a mash that was inoculated with an appropriate Salmonella surrogate at $71^{\circ} \mathrm{C}$, and that potential increased with increased temperature to $81^{\circ} \mathrm{C}$ and $88^{\circ} \mathrm{C}$ [69]. Other pieces of equipment like expanders, have been shown to reduce the pathogen load in feed around $10^{5}$ to $10^{6} \mathrm{cfu} / \mathrm{g}$ utilizing temperatures between $115^{\circ} \mathrm{C}$ and $125^{\circ} \mathrm{C}$, pressures up to 1,200 psi and exposure times of 10 to 20 seconds [70]. This piece of equipment is not 
commonly used for poultry feed, but could be utilized more if hygiene of the feed is desired to be improved, but could impact the nutrient availability due to the high temperatures utilized. Temperature is not the only factor that should be considered when looking at mitigation as the moisture in the feed can aid in mitigation potential.

Increasing moisture in feed from $5 \%$ to $15 \%$ showed to reduce the exposure time required to eliminate Salmonella in the temperature range of $71{ }^{\circ} \mathrm{C}-82^{\circ} \mathrm{C}$ [71]. To achieve high levels of mitigation, temperatures from $85^{\circ} \mathrm{C}$ to $93^{\circ} \mathrm{C}$ are needed for 90 seconds up to 4 minutes with moisture around $15 \%$ [71-72]. The extra moisture in the feed could aid in the thermal breaking of peptide bonds in the microorganism that will ultimately lead to the death of cell. These extended exposure times may have a positive impact on mitigation of pathogens like Salmonella, but once again could be detrimental to the nutrient availability of the feed. Temperature, moisture, and exposure time are not the only ways to mitigate pathogen load, but organic acids can also aid in the mitigation of pathogens if applied in the right concentrations and time of manufacture.

Inclusion of chemicals such as organic acids like, formic and propionic acid, to feed can aid in the destruction, inhibit growth, and prevent recontamination of microorganisms during and after the pelleting process [73]. Though, extended retention times of feed in the feed mill are needed for organic acids to achieve maximum efficiently. It has been demonstrated that mixtures of organic acids applied at 3\% to meat meals eliminated Salmonella over a 3-day period [74]. Use of $0.25 \%$ propionic acid added to feed has been shown to reduce colony forming units to less than 10 within 72 hours of application, with higher concentrations needed to reduce colony counts within 2 hours of application [75]. This may not be feasible for meat by-products and poultry feed, as large volumes are needed daily and so the by-product and feed may not get the needed exposure time to achieve maximum reduction. Use of chemicals can add another risk to feed mill personal, 
and so personal should be properly trained and protected from overexposure to chemicals [76]. Using organic acids could be a way to aid in mitigating pathogens in feed like Salmonella if the initial concentrations are low. This could be another method to aid in controlling pathogens in feed without having to use high conditioning temperatures that could result in negative effects on the final feed. Mitigation research can be conducted using nonpathogenic microorganisms, which is ideal in the research and commercial feed mill environments.

\section{Surrogates}

Enterococcus faecium (E. faecium) is a common surrogate used in research looking at reduction of Salmonella, with two common lab strains being ATCC 8459 and NRRL B-2354 [7778]. These strains of E. faecium are commonly used as they both lack the majority of virulence factors known for this species and are sensitive to medically relevant antibiotics [78]. Using a minimum temperature of $73^{\circ} \mathrm{C}$ has demonstrated to be able to produce a 5-log reduction in ATCC 8459 counts, while temperatures above $80^{\circ} \mathrm{C}$ resulted in no detectable levels of the organism to be counted [79]. Studies in the feed mill environment using short-term steam conditioning of 10 seconds demonstrated a 3-log reduction in a surrogate E. faecium, while long-term steam conditioning of 60 seconds resulted in a 4-log reduction in E. faecium [69]. Another surrogate that could be considered is Pediococcus acidilactici ( $P$. acidilactici), which has been used in lowmoisture pet food testing, which is comparable to poultry feeds as these are low moisture. Both $E$. faecium strains and $P$. acidilactici are ideal for thermal validation studies, $P$. acidilactici may be the superior option for studies under $90^{\circ} \mathrm{C}$ [77]. What could make $P$. acidilactici superior is that this organism has a lower heat resistance than E. faecium, which could make for P. acidilactici to be easier to work with when testing between temperatures of $60^{\circ} \mathrm{C}$ and $90^{\circ} \mathrm{C}$ [77]. These surrogates have an important role in mitigation research as they can be used in the feed mill 
environment without the worry of contaminating feed. These traits are what allows surrogates to be used to investigate how steam conditioning can impact the pathogen load of feed in the feed mill environment.

\section{Conclusions/Recommendations}

Feed manufacture and feed hygienics have major roles in the poultry production systems. Multiple factors go into producing hygienic and quality feed, and all factors must be considered and monitored. The most important factor to consider during feed manufacture is steam conditioning. If done properly, this step has the greatest impact on mitigation of pathogens. Use of higher steam conditioning temperatures also can improve bird performance by producing quality pellets and can reduce microbial load in feed, but could negatively impact nutrient availability of the feed. Obtaining ingredients from trusted suppliers that can verify there is no detectable pathogen is another way to aid in prevention of introducing pathogens to the feed and feed mill environment. Inclusion of pellet binders or other ingredients that act in a similar manner to pellet binders can be utilized to improve pellet quality when pelleted at lower conditioning temperatures, but could increase the risk of pathogens in the feed if not sourced from a reputable supplier. Time of addition of fat to the diet can have impacts on the final feed and thus must be considered during the feed manufacture process. New technology and feed ingredients will continue to come out and so feed producers must keep up to date on this information. A delicate balancing act must be done to achieve proper nutrition for the birds while also producing a hygienic feed.

\section{Future Research}

Future studies could use different conditioning temperatures and retention times and how these factors impact nutrient availability of the feed and pellet quality. Past research would suggest 
that pellet quality might be improved, but nutrient availability could be affected. Conducting more testing in commercial feed mills with surrogate organisms to see how these hold up in a commercial environment with larger batch sizes and equipment could also be beneficial to the knowledge base of feed microbiology. New technology and antimicrobials can also be considered to aid in pathogen reduction while still possibly maintaining the nutrient availability of the feed. New feed mill equipment, like hygenisers which subject feed to heat for an extended period, on pathogen reduction in feed and nutrient availability of feed. Additionally, antimicrobials could be tested with hygiensers to see if this combination improves feed hygiene and how it affects nutrient availability. Pellet binders, like Spirulina algae, could also be used in conjunction with hygiensers to see if the extra protein associated with the algae can negate some of the negative effects that could come from prolonged exposure to high temperatures. 


\section{REFERENCES}

1. International Feed Industry Federation. 2017. Global feed production. Accessed Nov. 2017. http://www.ifif.org/pages/t/Global feed production

2. Cutlip, S. E., J. M. Hott, N. P. Buchanan, A. L. Rack, J. D. Latshaw, and J. S. Moritz. 2008. The Effect of Steam-Conditioning Practices on Pellet Quality and Growing Broiler Nutritional Value. J. Appl. Poult. Res. 17:249-261.

3. Buchanan, N.P, and J. S. Moritz. 2009. Main effects and interactions of varying formulation protein, fiber, and moisture on feed manufacture and pellet quality. J. Appl. Poult. Res. 18:274-283.

4. Schoeff, R. W. 1994. History of the Formula Feed Industry. In: R.R. McEllhiney, ed. Feed Manufacturing Technology IV. American Feed Industry Association. Arlington, Virginia: 7.

5. Behnke, K.C. 1996. Feed manufacturing technology: current issues and challenges. Animal Feed Sci. and Tech. 62:49-57.

6. Behnke, K.C. 2001. Factors Influencing Pellet Quality. Feed Tech. https://pdfs.semanticscholar.org/43d9/1d59f6cda3cf69aa6f12e61ac1c33b832ec7.pdf

7. Thomas, M., and A.F.B. van der Poel. 1996. Physical quality of pelleted animal feed 1. Criteria for pellet quality. Animal Feed Sci. and Tech. 61:89-112.

8. Peisker, M. 2006. Feed Processing - Impacts on Nutritive Value and Hygienic Status in Broiler Feeds. Aust. Poult. Sci. Symp. 18:7-16.

9. Rumpf, H. 1958. Grundlagen und Methoden des Granulierens. Chemie-Ing.-Tech. 30:144-158.

10. Friedrich, W and K. F. Robohm.1969. Vergleichende Preßversuche mit unterschiedlichen Stoffeigenschaften auf dur Ring- un Scheibenmatrize, Kraftfutter. 52:59-64.

11. Vanschoubroek, F., L. Coucke, and R. Spaendonck. 1971. The quantitative effect of pelleting feed on the performance of piglets and fattening pigs. Nutr. Abstr. Rev. 41:1-9.

12. Pfost, H. B. 1963. Testing the durability of pelleted feed. Feedstuffs. 23:66-68.

13. Lilly, K. G. S., C. K. Gehring, K. R. Beaman, P. J. Turk, M. Sperow, and J. S. Moritz. 2011. Examining the relationships between pellet quality, broiler performance, and bird sex, J. Appl. Poult. Res. 20:231-239.

14. Bayley, H. S., J. D. Summers, and S. J. Slinger. 1968. The effect of steam pelleting feed ingredients on chick performance: Effect on phosphorus availability, metabolizable energy value and carcass composition. Poult. Sci. 4711401148.

15. Andrews, J. N. 1991. Pelleting: A review of why, how, value, and standards. Poult. Dig. 50:64-71.

16. Lambertini, E., A. Mishra, M. Guo, H. Cao, R. L. Buchanan, and A.K. Pradhan. 2016. Modeling the long-term kinetics of Salmonella survival on dry pet food. Food Microbiol. 58:1-6.

17. Loar, R. E. II, K. G. S. Wamsley, A. Evans, J. S. Moritz, and A. Corzo. 2014. Effects of varying conditioning temperature and mixer-added fat on feed manufacturing efficiency, 28- to 42-day broiler performance, early skeletal effect, and true amino acid digestibility. J. Appl. Poult. Res. 23:444-455. 
18. Boney, J. W., and J. S. Moritz. 2017. The effects of Spirulina algae inclusion and conditioning temperature on feed manufacture, pellet quality, and true amino acid digestibility. J. Ani. Feed Sci. 224:20-29.

19. Rexen, B. 1981. Use of enzymes for improvement of feed. Animal Feed Sci. and Tech. 6:105-114.

20. Jongbloed, A.W., and P. A. Kemme. 1990. Effect of pelleting mixed feeds on phytase activity and apparent absorbability of phosphorus and calcium in pigs. Animal Feed Sci. and Tech. 28:233-242.

21. Briggs, J. L., D .E. Maier, B. A. Watkins, K. C. Behnke. 1999. Effect of Ingredient and Processing Parameters on Pellet Quality. Poult. Sci. 78:1464-1471.

22. Glover, B. G., K. L. Foltz, I. Holásková, and J. S. Moritz. 2015. Effects of modest improvements in pellet quality and experiment pen size on broiler chicken performance. J. Appl. Poult. Res. 25:21-28.

23. Buchanan, N. P., K. G. S. Lilly, C. K. Gehring, and J. S. Moritz. 2010. The effects of altering diet formulation and manufacturing technique on pellet quality. J. Appl. Poult. Res. 19:112-120.

24. Koch, K. B. 2007. Pelleting and distiller's dried grains with solubles. http://www.biofuelscoproducts.umn.edu/sites/biodieselfeeds.cfans.umn.edu/files/cfans as set_414234.pdf

25. Loar, R. E. II, J. S. Moritz, J. R. Donaldson, and A. Corzo. 2010. Effects of feeding distillers dried grains with solubles to broilers from 0 to 28 days posthatch on broiler performance, feed manufacturing efficiency, and selected intestinal characteristics. Poult. Sci. 89:2242-2250.

26. Shim, M. Y., G. M. Pesti, R. I. Bakalli, P. B. Tillman, and R. L. Payne. 2011. Evaluation of corn distillers dried grains with solubles as an alternative ingredient for broilers. Poult. Sci. 90:369-376.

27. Wamsley, K. G. S., R. E. Loar II, K. Karges, and J. S. Moritz. 2013. The use of practical diets and regression analyses to determine the utilization of lysine and phosphorus in corn distillers dried grains and solubles using Cobb 500 male broilers. J. Appl. Poult. Res. 22:279-297.

28. Moritz, J. S., R. S. Beyer, K. J. Wilson, and K. R Cramer. 2001. Effect of Moisture Addition at the Mixer to a Corn-Soybean-Based diet on Broiler Performance. J. Appl. Poult. Res. 10:347-353.

29. Wamsley, K. G. S., and J. S. Moritz. 2013. Resolving poor pellet quality and maintaining amino acid digestibility in commercial turkey diet feed manufacture, J. Appl. Poult. Res. 22:439-446.

30. Gehring, C. K., K. G. S. Lilly, L. K. Shires, K. R. Beaman, S. A. Loop, and J. S. Moritz. 2011. Increasing mixer-added fat reduces the electrical energy required for pelleting and improves exogenous enzyme efficacy for broiler. J. Appl. Poult. Res. 20:75-89.

31. Jones, F.T. 2011. A review of practical Salmonella control measures in animal feed. J. Appl. Poult. Res. 20:102-113.

32. World Health Organization. 2017. Salmonella (non-typhoidal). Accessed Dec. 2016. http://www.who.int/mediacentre/factsheets/fs139/en/

33. Cox, N.A., D. Burdick, J.S Bailey, and J. E. Thomson. 1986. Effect of the Steam Conditioning and Pelleting Process on the Microbiology and Quality of CommercialType Poultry Feeds. Poult. Sci. 65:704-709. 
34. Winfield, M.D., and E. A. Groisman. 2003. Role of non-host environments in the lifestyle of Salmonella. Appl. Environ. Microbiol. 69: 3687-3694.

35. Humphrey, T. 2004. Salmonella, stress responses and food safety. Nat. Rev. Microbiol. 2: 504-509.

36. Blackman, J., T. Bowman, J. Chambers, J. Kisllenki, J. Parr, A. M. St-Laurent, and J. Thompson. 1993. Controlling Salmonella in livestock and poultry feeds. Agriculture Canada, Ottawa, Canada.

37. Juven, B. J., N. A. Cox, J. S. Bailey, J. E. Thomson, O. W. Charles, and J. V. Shutze. 1984. Survival of Salmonella in dry food and feed. J. Food Prot. 47:445-448.

38. Greco, M., A. Pardo, G. Pose, and A. Patriarca. 2017. Effects of water activity and temperature on the growth of Eurotium species isolated from animal feeds. Rev Iberoam Micol. 35:39-48.

39. Davies, R. H, and C. Wray. 1997. Distribution of Salmonella contamination in ten animal feedmills. Vet. Med. 57:159-169.

40. Scallan, E., R. M. Hoekstra, F. T. Angulo, R. V. Tauxe, M.-A. Widdowson, S. L. Roy, J. L. Jones, and P. M. Griffin. 2011. Foodborne Illness Acquired in the United StatesMajor Pathogens. Emerging Infectious Diseases. 17:7-15.

41. Andino, A., S. Pendleton, N. Zhang, W. Chen, F. Critzer, and I. Hanning. 2014. Survival of Salmonella enterica in poultry feed is strain dependent. Poultry Science. 93:441-447.

42. Papadopoulou, C., J. J. Carrique-Mas, R. H. Davies, and A. R. Sayers. 2009. Retrospective analysis of Salmonella isolates recovered from animal feed in Great Britain. Vet. Record. 165:681-688.

43. Centers for Disease Control and Prevention (CDC). 2018. Burden of Foodborne Illness: Findings. Accessed Jan. 2019. https:/www.cdc.gov/foodborneburden/2011-foodborneestimates.html

44. U.S. Food \& Drug Administration (FDA). 2018. Veterinary Feed Directive (VFD). Accessed Jan. 2019. https://www.fda.gov/animalveterinary/developmentapprovalprocess/ucm071807.htm

45. Ricke, S. C., M. M. Kundinger, D. R. Miller, and J. T. Keeton. 2005. Alternatives to antibiotics: Chemical and physical antimicrobial interventions and foodborne pathogen response. Poult. Sci. 84:667-675.

46. Jones, F. T. 2008. Control of toxic substances. Feedstuffs. 80:77-81.

47. Jones, F.T., K. E. Richardson. 2004. Salmonella in Commercially Manufactured Feeds. Poult. Sci. 83:384-391.

48. Ratcliff, J. 2006. Pathogen control in feedmills. Pages 45-49 in Feed Processing and Quality Control. Technical Report Series. Am. Soybean Assoc., Int, Marketing, Southeast Asia, Singapore.

49. Anonymous. 2001. Effective Salmonella control in the feed mill. Intern. Hatch. Pract. 15:17.

50. McCarty, R. M. 2005. Receiving. Pages 91-107 in Feed Manufacturing Technology V. S. K. Schofield, ed. Am. Feed Ind. Assoc., Arlington, VA.

51. McDaniel, G. L. 2005. Dust Collection Systems. Pages 230-238 in Feed Manufacturing Technology V. S. K. Schofield, ed. Am. Feed Ind. Assoc., Arlington, VA.

52. Morita, T., H. Kitazawa, T. Iida, and S. Kamata. 2006. Prevention of Salmonella crosscontamination in an oilmeal manufacturing plant. J. Appl. Microbiol. 101:464-473. 
53. D’Aoust, J. Y. 1997. Salmonella Species. Pages 129-158 in Food Microbiology: Fundamentals and Frontiers. M. P. Doyle, L. R. Beuchat, and T. J. Montville, ed. ASM Press, Washington DC.

54. Nayak, R. R. 2000. Foodborne pathogens in poultry production and post-harvest control. PhD Diss. West Virginia University, Morgantown.

55. Benskin, C. M. H., K. Wilson, K. Jones, and I. R. Hartley. 2009. Bacterial Pathogens in wild birds: A review of frequency and effects of infection. Biol. Rev. Camb. Philos. Soc. 84:349-373.

56. Jones, F. T., and S. C. Ricke. 1994. Researchers propose tentative HACCP plan for feed mills. Feedstuffs 66(5):32, 36-42.

57. Fedorka-Cray, P. J., A. Hogg, J. T. Gray, K. Lorenzen, J. Velasquez, and P. Von Behren. 1997. Feed and feed trucks as sources of Salmonella contamination in swine. Swine Health Prod. 5:189-193.

58. Whyte, P., K. McGill, and J. D, Collins. 2003. A survey of the prevalence of Salmonella and other enteric pathogens in a commercial poultry feed mill. J. Food Saf. 23:13-24.

59. Shi, X., and X. Zhu. 2009. Biofilm formation and food safety in food industries. Trends in Food Science \& Technology, 20: 407-413.

60. Rosentrater, K. A., and G. D. Williams. 2004. Design considerations for the construction and operation of feed milling facilities. Part II. Process engineering considerations. Am. Soc. Agric. Eng. (ASAE)/Canad. Soc. Agric. Eng. Mtg. Paper No. 044144. ASAE, St. Joseph, MI.

61. Israelsen, M., and I. D. Hansen. Elimination of Salmonella in dry feeds.

62. van Schothorst, M., and A. W. M. Brooymans. 1982. Effect of processing on microbial contaminants in feed. Pages 371-385 in Handbook of Nutritive Value of Processed Food. Vol. II: Animal Feedstuffs. Miloslav Rechcigl Jr., ed. CRC Press, Boca Raton, FL.

63. Stott, J. A., J. E. Hodgson, and J. C. Chaney. 1995. Incidence of Salmonellae in animal feed and the effect of pelleting on content of Enterobacteriaceae. J. Appl. Bacteriol. 39:41-46.

64. Veldman, A., H. A. Vahl, G. J. Borrggreve, and D.C. Fuller. 1995. A survey of the incidence of Salmonella species and Enterobacteriaceae in poultry feeds and feed components. Vet. Rec. 136:169-172.

65. Obi, S. K. 1978. The effects of pelleting and gamma irradiation on the microbial population of animal diets. Zentralblatt für Veterinärmedizin Reihe B. 25:178-185.

66. Furuta, K., I. Oku, and S. Morimoto. 1980. Effect of steam conditioning in the pelleting process of chicken food on the viability of contaminating bacteria. Lab. Anim. 14:293296

67. Cox, N.A., D. Burdick, J.S. Bailey, and J.E. Thomson. 1986. Effect of the Steam Conditioning and Pelleting Process on the Microbiology and Quality of Commercial-Type Poultry Feeds. Poult. Sci. 65:704-709.

68. Jones, F.T., K. E. Richardson. 2004. Salmonella in Commercially Manufactured Feeds. Poult. Sci. 83:384-391.

69. Boney, J. W., J. Jaczynski, J. L. Weidhaas, A. N. Bergeron, and J. S. Moritz. 2018. The effects of steam conditioning and antimicrobial inclusion on feed manufacture and inactivation of Enterococcus faecium, a Salmonella surrogate. J. Appl. Poult. Res. 0:1-11.

70. Francher, B., L. D. Rollins, and B. Trimbee. 1996. Feed processing using the annular gap expander and its impact on poultry performance. J. Appl. Poult. Res. 5:386-394. 
71. Himathongkham S., M. dasGraças Pereira, and H. Riemann. 1996. Heat destruction of Salmonella in poultry feed: effect of time, temperature, and moisture. Avian Dis. 40:7277.

72. McCapes R., H. Ekperigin, W. Cameron, W. Ritchie, J. Slagter, V. Stangeland, and K. Nagaraja. 1989. Effect of a new pelleting process on the level of contamination of poultry mash by Escherichia coli and Salmonella. Avian Dis. 33:103-111.

73. Carrique-Mas, J. J., S. Bedford, and R. H. Davies. 2007. Organic acid and formaldehyde treatment of animal feeds to control Salmonella: efficacy and masking during culture. J. Appl. Microbiol. 103:88-96.

74. Phelps, A. 1989. Organic acids found effective in killing Salmonella in poultry feed, animal protein. Feedstuffs. July $3^{\text {rd }}$.

75. John, R. E., D. J., Castaldo, and S. Sulaiman. 1989. Control at the mill. Feed Managament August. 27.

76. Sheldon, B. W., and J. Brake. 1991. Hydrogen peroxide as an alternative hatching egg disinfectant. Poult. Sci. 70:1092-1098.

77. Ceylan, E., D. A. Bautosta. 2015. Evaluating Pediococcus acidilactici and Enterococcus faecium NRRL B-2354 as Thermal Surrogate Microorganisms for Salmonella for InPlant Validation Studies of Low-Moisture Pet Food Products. J. of Food Protection. 78:934-939.

78. Kopit, L. M., E.B. Kim, R.J. Siezen, L.J. Harris, and M.L. Marco. 2014. Safety of the surrogate microorganism Enterococcus faecium NRRL B-2354 for use in thermal process validation. Appl. and Envi. Microbiol. 80:1899-1909.

79. Bianchini, A., J. Stratton, S. Weier, T. Hartter, B. Plattner, G. Rokey, G. Hertzel, L. Gompa, B. Martinez, and K. M. Eskridge. 2014. Use of Enterococcus faecium as a Surrogate for Salmonella enterica during Extrusion of a Balanced Carbohydrate-Protein Meal. J. of Food Protection. 77:75-82. 


\section{CHAPTER TWO}

The Effect of Standard Pelleting and More Thermally Aggressive Pelleting utilizing a Hygieniser on Feed Manufacture and Reduction of Enterococcus faecium, a Salmonella

\section{Surrogate}

T. P. Boltz ${ }^{1}$, J. W. Boney ${ }^{2}$, C. Shen ${ }^{1}, J$ Jaczynski ${ }^{1}$ and J. S. Moritz ${ }^{1}$

${ }^{1}$ Division of Animal and Nutritional Science, West Virginia University, Morgantown, West

Virginia, 26506

Phone: 304-293-1911

Fax: 304-293-2232

${ }^{2}$ Department of Animal Science, Pennsylvania State University, University Park, Pennsylvania, 16802

Phone: $814-865-1362$

Fax: 814-863-6042 


\section{SUMMARY}

Feed hygienics are of ever increasing importance in providing safe feed to animals, and ultimately safe food for consumers. Salmonella has been identified as a major microbial hazard in animal feed that has been linked to illness in both animals and humans. Use of antibiotics has decreased in recent years due to policies and practices of poultry production, increasing opportunities for potential pathogens in feed to affect poultry and poultry products. New feed equipment technology provides an option to combat feed pathogens. For example, hygienisers have been suggested to decrease Salmonella associated with mash feeds due to the ability to maintain conditioned feed temperature for an extended time. Enterococcus faecium (E. faecium) is a non-pathogenic surrogate used to study reduction of Salmonella. The objective of the current study was to compare feed manufacture and Salmonella surrogate (E. faecium ATCC 8459) reduction differences between standard pelleting and more thermally aggressive pelleting utilizing a hygieniser. More thermally aggressive pelleting decreased pellet mill motor load $(\mathrm{P}=0.02)$, increased hot pellet temperature $(\mathrm{P}=0.02)$, and tended to increase pellet durability $(\mathrm{P}=0.07)$. E. faecium ATCC 8459 colonies decreased with standard pelleting relative to inoculated mash and were reduced further with more thermally aggressive pelleting $(\mathrm{P}<0.05)$. Standard pelleting and more thermally aggressive pelleting resulted in a 3 and 4-log reduction in E. faecium ATCC 8459 respectively, relative to inoculated mash. More thermally aggressive pelleting utilizing a hygieniser may improve manufacture efficiency, pellet quality, and Salmonella reduction.

Key words: Hygieniser, Salmonella, Bacterial Reduction, Pelleting, Feed 


\section{DESCRIPTON OF PROBLEM}

Feed safety has been of ever increasing concern since the 2011 signing of the Food and Drug Administration's Food Safety Modernization Act (FSMA) into law. The Centers for Disease Control and Prevention estimate that every year in the United States approximately 48 million people get sick, 128,000 are hospitalized, and 3,000 die from a food borne illness [1]. Salmonella is a major microbial hazard in animal feeds, and is difficult to eliminate from feed ingredients [2]. Poultry can become infected with Salmonella from feed manufactured with contaminated ingredients, and maintained in poultry products. Feed microbiology is a new field of science that may help control pathogens in animal feed.

Industry standards for manufacturing pelleted feeds do not exist, and commercial and integrated feed mills have varied standards of production practices. Antibiotic use in live bird production is on the decline due to policies, practices and marketing; therefore, new methods to control possible pathogenic bacteria in feed such as Salmonella, should be investigated. Use of new feed technology available to feed producers may be implemented to reduce the microbial load in feed, which could ultimately aid in producing safe poultry products for consumers.

Use of higher conditioning temperature, antimicrobial inclusion such as organic acids, and other pieces of equipment like expanders have been used to reduce feed Salmonella [2]. A new piece of feed equipment technology that could further aid in pathogen reduction in poultry feed is a hygieniser. High temperatures have been shown to have destructive effects on Salmonella and other pathogens that may be present in food [3]. Feed can be retained in the barrel of the hygieniser and maintained at a desired conditioning temperature through jacketed heat, which may aid in the destruction of pathogens. Extended retention times have been shown in past literature to reduce contamination of feed. A retention time of 60 seconds at conditioning temperatures of $71^{\circ} \mathrm{C}, 82^{\circ} \mathrm{C}$, 
and $88^{\circ} \mathrm{C}$ has demonstrated a reduction of Enterococcus faecium ATCC 8459 in feed up to 4-log, while short term conditioning for 10 seconds at the same temperatures demonstrated a $3-\log$ reduction in the same organism [4]. Enterococcus faecium ATCC 8459 has been used in past research as an appropriate surrogate for mitigation in feed and poultry products as well as being inactivated at higher temperatures [4-6]. Surrogate organisms do not carry the risks associated with the pathogen of interest and are safer to use when investigating mitigation techniques.

Thermal processing in the form of steam conditioning is a variable that can be manipulated by feed producers. Steam conditioning temperature serves as the critical control point in feed manufacture that reduces the microbial load of the feed [7]. In addition to mitigation potential, pellet quality can be improved with increased conditioning temperature [8-10]. Conversely, steam conditioning can have detrimental effects on nutrient digestibility and retention of mixer added enzymes [8-11]. Therefore, understanding thermal processing variables that mitigate pathogens, improve pellet quality, and avoid nutrient digestibility detriment are critical to optimizing poultry production.

The objective of the current study was to compare differences between standard pelleting and more thermally aggressive pelleting utilizing a hygieniser on feed manufacture efficiency, pellet quality and the viability of Enterococcus faecium ATCC 8459, an appropriate nonpathogenic surrogate for Salmonella.

\section{MATERIALS AND METHODS}

\section{Experiential Design}

Two pelleting techniques, standard pelleting with a goal conditioning temperature of $70^{\circ} \mathrm{C}$ for 15 seconds without hygieniser use and more thermally aggressive pelleting with a goal conditioning 
temperature of $80^{\circ} \mathrm{C}$ for 30 second and hygieniser use for 45 seconds, were applied to three replicated $226.8 \mathrm{~kg}$ batches of broiler feed inoculated with Enterococcus faecium ATCC 8459 over a three-day feed manufacture period in a randomized complete block design.

\section{Diet Formulation, Batching, and Feed Manufacture}

A basal diet was formulated using AgriStat data [12] as a nutrient reference for growing broiler chickens. A master batch of $1,360.8 \mathrm{~kg}$ was created and then split into three replications of $453.6 \mathrm{~kg}$. This was then split again into two $226.8 \mathrm{~kg}$ batches for the two dietary treatments to be manufactured each day. From each $226.8 \mathrm{~kg}$ batch, $21.5 \mathrm{~kg}$ of feed was collected to be inoculated with Enterococcus faecium inoculum broth. All feed was manufactured at the West Virginia University pilot feed mill located in Morgantown, West Virginia. A California Pellet mill conditioner, hygieniser and 40 HP California Pellet Mill [13] were used for conditioning and pelleting, where pellets were extruded through a 4.7 × $38 \mathrm{~mm}$ pellet die. Production rate was constant at $1.2 \mathrm{MT} / \mathrm{hr}$ among all replications of manufacture. One allotment of basal diet, $204 \mathrm{~kg}$, was conveyed to a surge bin above the conditioner, and used to obtain and maintain desired conditioning temperature of $70^{\circ} \mathrm{C}$ for standard pelleting and $80^{\circ} \mathrm{C}$ for more thermally aggressive pelleting. After the desired temperature had been achieved and the feed probe sensor in the back of the surge bin above the pellet mill was exposed, $22.8 \mathrm{~kg}$ of inoculated feed was added into the surge bin to be pelleted. This was done when the probe was exposed to ensure the right samples would be collected and to prevent the system from shutting down and losing the desired conditioning temperature.

Standard pelleting runs had the hygieniser turned off so no additional jacketed heat was applied to the feed as there is no way to bypass the hygieniser in this feed manufacture system. More thermally aggressive pelleting had the hygieniser turned on, so the mash feed was exposed 
to additional heat for another 45 seconds after initial conditioning for 30 seconds. Conditioner, hygieniser temperature and pellet mill motor amperage were recorded at this time using a Beta Raven programmable logic control (PLC) system [14]. Two minutes after the inoculated feed was added into the surge bin, pellet samples were collected directly post extrusion from the pellet die. This technique ensured that pellet samples were from the inoculated feed. Pellet samples were placed on cheesecloth on top of a large agriculture fan that pulled ambient air across the pellets for a standardized time of 12 minutes to allow the pellets to cool and dry. This follows methodologies from Reese et al. [15], that limits potential nutrient segregation effects of post pellet auguring. In addition, a portion of pelleted sample was assayed for hot pellet temperature using an insulated container to catch pellets, then immediately closing the lid, and inserting a thermocouple thermometer [16] with an 80PK-24 temperature probe.

After the 12-minute cooling and drying period, a $500 \mathrm{~g}$ portion of the pellet sample was placed in a Whirl-Pak bag [17] and flash frozen in liquid nitrogen to maintain bacterial integrity. Following flash freezing, samples were stored at $-80^{\circ} \mathrm{C}$ until Enterococcus faecium analysis. Additional pellets sampled from the cooler deck were assayed for pellet quality.

\section{Pellet Quality Analysis}

Approximately 24 hours post-pelleting, pellet quality was determined utilizing a New Holman pellet tester (NHPT) [18]. A pelleted sample from each treatment was sifted using a No. 6 W.S. Tyler testing sieve [19]. One hundred grams samples of sifted pellets were placed in the NHPT perforated chamber, where forced air was applied for 30 seconds and the remaining pellet samples were weighed and recorded as a percentage to determine pellet durability. Pellet quality analyses were conducted in triplicate for each treatment and results reflect average pellet durability. 


\section{Non-pathogenic Surrogate Microorganism}

Enterococcus faecium ATCC 8459 (American Type Culture Collection, Manassas, Virginia), herein referred to as E. faecium was selected to be the non-pathogenic surrogate microorganism for this experiment based on use in previous work [4-6,20]. Brain heart infusion (BHI) broth was used to prepare E. faecium culture [3, 21]. BHI broth was prepared by dissolving BHI powder in deionized water followed by sterilization in an autoclaved at $121^{\circ} \mathrm{C}$ for 15 minutes. A freeze-dried E. faecium pellet was rehydrated in sterile BHI broth. A five percent inoculum of rehydrated E. faecium was then aseptically transferred to tryptic soy broth (TSB) [22] with five percent defibrinated sheep blood [23] and incubated for 24 hours at $26^{\circ} \mathrm{C}$ using a rotary incubator shaker [24] at 100 revolutions per minute. This provided the initial culture of E. faecium. A stock culture of E. faecium was prepared by combining equal volume of glycerol and the initial culture. The stock culture was and stored at $-80^{\circ} \mathrm{C}$.

Prior to feed inoculation, the stock culture was thawed under running tap water. A five percent inoculum of thawed stock culture was aseptically transferred to $500 \mathrm{~mL}$ of sterile TSB supplemented with five percent defibrinated sheep blood followed by incubation for 24 hours at $26^{\circ} \mathrm{C}$ using a rotary incubator shaker. This process yielded the E. faecium culture that was used to inoculate feed.

\section{Feed Inoculation and Incubation}

Feed inoculation and bacterial incubation followed Boney et al. [3], where TSB powder was dissolved in deionized water and sterilized by autoclaving at $121^{\circ} \mathrm{C}$ for 15 minutes. The sterile TSB was cooled to approximately $47^{\circ} \mathrm{C}$ before defibrinated sheep blood was added at a five percent inclusion and then gently mixed. A sterilized inoculation loop was inserted into the of $E$. 
faecium stock culture and then aseptically transferred to the TSB to initiate bacterial propagation. Inoculum was placed in an incubator shaker for 24 hours at $26^{\circ} \mathrm{C}$ at 100 revolutions per minute.

It is important to note that none of the feed was sterilized before inoculation. A $21.5 \mathrm{~kg}$ feed allotment was placed in a Triumph paddle mixer, where five percent $(\mathrm{wt} / \mathrm{wt})(1.3 \mathrm{~kg})$ inclusion of inoculum was applied to the feed and allowed to mix for five minutes. This provided a $22.8 \mathrm{~kg}$ treatment that would be added back to an untreated $204 \mathrm{~kg}$ of basal diet to achieve the total 226.8 $\mathrm{kg}$ experimental unit for each treatment. After mixing, mash samples ( $\sim 500$ gram) were collected in Whirl-Pak bags and submerged in liquid nitrogen to maintain bacterial integrity and stored ($80^{\circ} \mathrm{C}$ ) until analysis. The remaining inoculated feed was transferred to the West Virginia University pilot feed mill to be pelleted.

\section{Enumeration of Enterococcus faecium in Mash and Pelleted Feed}

The following procedures were conducted to enumerate E. faecium, which follow Boney et al. [3]. Pelleted feed samples were removed from storage at $-80^{\circ} \mathrm{C}$ and pulverized using a sterile mortar and pestle. A two-gram sample of either unconditioned mash or pulverized pellet was weighed and aseptically placed in a sterile, $50 \mathrm{~mL}$ conical tube [25]. Phosphate buffered saline (1xPBS) [26] was added to the conical tube containing either mash or pulverized pellets to create a 50-mL solution. The solution was agitated by hand to suspend E. faecium in the 1xPBS solution. Following agitation, serial dilutions were prepared by placing nine $\mathrm{mL}$ of $1 \mathrm{xPBS}$ in five sterilized, $20 \mathrm{~mL}$ glass tubes. A quantity of one $\mathrm{mL}$ of the feed and PBS solution was transferred to a serial dilution tube, covered with parafilm, and inverted multiple times, creating a 1:10 dilution. Subsequent serial dilutions were carried out $(1: 10-1: 1,000,000)$. Contents from each dilution tube were passed through a $0.45 \mu \mathrm{m}$ gridded membrane filter [27] using vacuum filtration. Post vacuum filtration, each filter was placed on an m-Enterococcus agar plate [28], inverted, and placed in an 
incubator for 48 hours at $35^{\circ} \mathrm{C}$. Following incubation, typical pink/purple E. faecium colonies were counted and recorded. Colony counts were derived from two g feed samples, so counts were divided by two and reported as colony forming units per gram of feed $\left(\log _{10} \mathrm{CFU} / \mathrm{g}\right)$. Enumeration was performed in triplicate for each pelleting technique and then averaged. These methods were performed on each of the three replicates of feed samples. Relative reduction percentage was calculated using the following equation:

$$
100 \text { - ((Pellet CFU/g) / (Mash CFU/g)). }
$$

\section{Statistical Analysis}

Feed manufacture pelleting technique was replicated three times over a three-day period with a single $226.8 \mathrm{~kg}$ allotment of feed serving at the experimental unit. Treatments were randomly ordered per day to achieve a randomized complete block design. Data were analyzed using the GLM procedure of Statistical Analysis System [29] and alpha was designated to be $\mathrm{P} \leq 0.05$. Mash and pelleted samples were utilized in the analysis for bacteria colony count. Significant effects were further explored via post hoc protected Fisher's least significant difference test for bacteria colony count data.

\section{RESULTS AND DISCUSSION}

The basal diet is shown in Table 1. Feed manufacture and bacteria colony count results are depicted in Table 2 . The more thermally aggressive pelleting technique increased conditioner and hygieniser temperature relative to standard pelleting $(\mathrm{P}<0.05)$ as designed. More thermally aggressive pelleting also decreased motor load and increased hot pellet temperature $(\mathrm{P}<0.05)$. Pellet temperature effect was associated with treatment design. The decreased pellet mill motor load can be attributed to increased moisture at the pellet die due to greater steam volume to obtain the higher conditioning temperature providing more lubrication. These results agree with past 
literature that demonstrated a reduction of motor load with elevated conditioning temperatures $[8$, 30-31]. Pellet durability tended to increase from standard pelleting to more thermally aggressive pelleting $(\mathrm{P}=0.07)$. Table 2 shows an increase of 21 percentage points for more thermally aggressive pelleting. The additional moisture and heat retention time could aid in starch gelatinization and protein gelation, as demonstrated in past literature [10, 32-33]. This particular magnitude of pellet durability improvement is important due to past literature describing broiler performance improvement when fed pellets that varied in similar percentage points [8, 34-35].

Reduction of E. faecium was significant between standard and more thermally aggressive pelleting. The untreated mash started with 88,389 colonies and after standard and more thermally aggressive pelleting, it was reduced to 2,822 and 320 colonies respectively. From a microbiology perspective, this is a 3- and 4-log reduction for standard pelleting and more thermally aggressive pelleting. These results agree with general claims suggesting that pelleting aids in the destruction of pathogens in feed [36]. Generally, a 5-log reduction of a target pathogen is considered sufficient for pasteurization, which is defined as "partial sterilization of a substance at a temperature and for a period of exposure that destroys objectionable organisms without major chemical alteration of the substance" [37]. The current study did not achieve pasteurization, but future research could investigate increased temperature and time to achieve pasteurization.

Addition of an antimicrobial, such as a formaldehyde amalgam, and use of a hygieniser could result in greater mitigation of bacteria in feed. Boney et al. [4], utilized mixer-added antimicrobial inclusion and varying temperatures of steam conditioning and found that inclusion of an antimicrobial decreased E. faecium colony counts when applied to mash feed that was inoculated and mitigation potential increased when mash was conditioned at higher conditioning temperatures with antimicrobial addition. Jones et al. saw that application of formaldehyde to feed 
that was preconditioned at $82^{\circ} \mathrm{C}$ for 60 seconds, and then subjected to extended heat in a hygieniser for 4.5 minutes had minimal impact on amino acid digestibility [38]. The effect of hygieniser use on feed nutrients using additional feed manufacture variables should be addressed with additional studies.

Essential nutrients can be damaged at high conditioning temperatures, which could be utilized to combat pathogens associated with feed. Cutlip et al. found a $6.7 \%$ loss of vitamin A when feed was conditioned and pelleted at $93^{\circ} \mathrm{C}$ [8]. Leucine, valine, isoleucine, alanine, and aspartic acid digestibility have been shown to decrease in diets conditioned at $91{ }^{\circ} \mathrm{C}$ relative to 74 and $82^{\circ} \mathrm{C}$ [10]. Loar et al. also found that methionine, isoleucine, and proline had significantly reduced digestibility when conditioned at 85 and $96^{\circ} \mathrm{C}$ relative to $74^{\circ} \mathrm{C}$ [9]. Use of more thermally stable enzymes should be considered as certain enzymes can be compromised at high conditioning temperatures and retention times [11,39-41]. Though conditioning temperatures and retention times utilized for this study were not as extreme relative to some commercial practices, more research is needed determine optimal temperatures and retention times for pathogen reduction while still considering nutrient availability and pellet quality.

Results from this study suggest that use of a hygieniser can not only reduce possible pathogenic organisms in feed, but also improve feed manufacture metrics and pellet quality. 


\section{CONCLUSION AND APPLICATIONS}

1. More thermally aggressive pelleting, i.e. $80^{\circ} \mathrm{C}$ conditioning for 30 seconds and 45 seconds retention in a hygieniser, increased pellet durability and showed more Salmonella reduction potential compared to standard pelleting.

2. Pellet mill motor load was decreased with more thermally aggressive pelleting.

3. Within the parameters of this study, standard pelleting demonstrated a 3-log reduction in an inoculated surrogate organism while more thermally aggressive pelleting demonstrated a 4-log reduction.

\section{REFERENCES AND NOTES}

1. Centers for Disease Control and Prevention. Burden of Foodborne Illness: Overview. Accessed Jul. 2018. https://www.cdc.gov/foodborneburden/estimates-overview.html.

2. Jones, F.T. 2011. A review of practical Salmonella control measures in animal feed. J. Appl. Poult. Res. 20:102-113.

3. Jay, J. M., M. J. Loessner, and D. A. Golden. 2005. Food Protection with High Temperatures, and Characteristics of Thermophili Microorganisms. Pages 415-442 in Modern Food Microbiology. Springer Science + Business Media, New York, NY.

4. Boney, J. W., J. Jaczynski, J. L. Weidhaas, A. N. Bergeron, and J. S. Moritz. 2018. The effects of steam conditioning and antimicrobial inclusion on feed manufacture and inactivation of Enterococcus faecium, a Salmonella surrogate. J. Appl. Poult. Res. 0:111.

5. Lemonakis, L., K. Li, J. M. Adler, and C. Shen. 2017. Microbiological quality assessment and validation of antimicrobials agents against unstressed or cold-stress adapted Salmonella and surrogate Enterococcus faecium on broiler carcasses and wings. Poult. Sci. 96:4038-4045.

6. Bianchini, A., J. Stratton, S. Weier, T. Hartter, B. Plattner, G. Rokey, G. Hertzel, L. Gompa, B. Martinez, and K. M. Eskridge. 2014. Use of Enterococcus faecium as a surrogate for Salmonella enterica during Extrusion of a Balanced CarbohydrateProtein Meal. J. Food. Prot. 77:75-82.

7. Huleback, K. L. and W. Schlosser. 2002. Hazard Analysis and Critical Control Point (HACCP) History and Conceptual Overview. Risk Analysis 22: 547-552.

8. Cutlip, S. E., J. M. Hott, N. P. Buchanan, A. L. Rack, J. D. Latshaw, and J. S. Mortiz. 2008. The Effect of Steam-Conditioning Practices on Pellet Quality and Growing Broiler Nutritional Value. J. Appl. Poult. Res. 17:249-261.

9. Loar II, R. E., K. G. S. Wamsley, A. Evans, J. S. Moritz, and A. Corzo. 2014. Effects of varying conditioning temperature and mixer-added fat on feed manufacturing efficiency, 28- to 42-day broiler performance, early skeletal effect, and true amino acid digestibility. J. Appl. Poult. Res. 23:444-455. 
10. Boney, J. W. and J. S. Moritz. 2017. The effects of Spirulina algae inclusion and conditioning temperature on feed manufacture, pellet quality, and true amino acid digestibility. Anim. Feed Sci. Technol. 224:20-29.

11. Jongbloed, A.W., and P. A. Kemme. 1990. Effect of pelleting mixed feeds on phytase activity and apparent absorbability of phosphorus and calcium in pigs. Animal Feed Sci. and Tech. 28:233-242.

12. AgriStats Inc., Fort Wayne, IN.

13. Master Model Pellet Mill, California Pellet Mill Company, Crawfordsville, IN.

14. Beta Raven Automation Solutions, St. Charles, MO.

15. Reese, D. A., K. L. Foltz, and J. S. Moritz. 2017. Effect of mixing and sampling method on pelleted feed nutrient analysis and diet formulation validation. J. Appl. Poult. Res. 26:219-225.

16. Fluke 51 II, Everette, WA.

17. Nasco Whirl-Pak ${ }^{\mathrm{TM}}$ Easy-To-Close Bags. 18.5 x $7.5 \mathrm{~cm}$. Mechanicsburg, PA.

18. New Holmen Portable Pellet Durability Tester, Lignotech USA Inc., Rothschild, WI.

19. U.S.A Standard Test Sieve. No. 6. W.S. Tyler. Mentor, OH.

20. American Type Culture Collection. Manassas, VA. Global Bioresource Center. Accessed Nov. 2018. https://www.atcc.org/.

21. Brain Heart Infusion Broth. Sigma-Aldrich, St. Louis, MO.

22. Tryptic soy broth, Difco, Beston, Dickinson and company, Franklin Lakes, NJ.

23. Defibrinated Sheep Blood, Hemostat Laboratories, Dixon, CA.

24. Classic Series C24 Incubator Shaker. New Brunswick Scientific Co., INC. Edison, NJ.

25. 50-mL Conical Tube, Corning Inc., Corning, NY.

26. 1xPBS, Life Technologies, Grand Island, NY.

27. Mixed ester cellulose membrane filter, Fisherbrand, Ottawa, Ontario.

28. m-ENT agar, Neogen Corporation, Lansing, MI.

29. SAS Institute. 2017. The SAS System for Windows 2017. Release 9.4 SAS Inst. Inc., Cary, NC.

30. Moritz, J.S., K. R. Cramer, K. J. Wilson, and R. S. Beyer. 2003. Feed manufacture and feeding of rations with graded levels of added moisture formulated to different energy densities. J. Appl. Poult. Res. 12:371-381.

31. Corey, A. M., K. G. S. Wamsley, T. S. Winowiski, and J. S. Moritz. 2014. Effects of calcium lignosulfonate, mixer-added fat, and feed form on feed manufacture and broiler performance. J. Appl. Poult. Res. 23:418-428.

32. Moritz, J. S., R. S. Beyer, K. J. Wilson, and K. R. Cramer. 2001. Effect of moisture at the mixer to a corn-soybean-based diet on broiler performance. J. Appl. Poult. Res. 10:347-353.

33. Buchanan, N. P., K. G. S. Lilly, C. K. Gehring, and J. S. Moritz. 2010. The effects of altering diet formulation and manufacturing technique on pellet quality. J. Appl. Poult. Res. 19:112-120.

34. Glover, B. G., K. L. Foltz, I. Holásková, and J. S. Moritz. 2015. Effects of modest improvements in pellet quality and experiment pen size on broiler chicken performance. J. Appl. Poult. Res. 25:21-28. 
35. Lemons, M. E. and J. S. Moritz. 2015. The effect of feeder space access and crumbleor pellet-to-fine ratio on 38-day-old broiler performance. J. Appl. Poult. Res. 25:1220.

36. Behnke, K.C. 1994. Factors affecting pellet quality. Proc. Maryland Nutrition Conference. 20-25 March 1994. Department of Poultry Science and Animal Science, College of Agriculture, University of Maryland, College Park.

37. Merriam-Webster Dictionary. Accessed Nov. 2018. https://www.merriamwebster.com/dictionary/pasteurization.

38. Jones, M. K., K. E. Richardson, C. W. Starkey, N. M. Dale, and A. J. Davies. 2018. Impact of Extended Heat Treatment on the Amino Acid Digestibility and TMEn Content of a Formaldehyde-Treated Diet. J. Appl. Poult. Res. 98:1-5.

39. Wilkinson, S. J., C. L. Walk, M. R. Bedford, and A. J. Cowieson. 2013. Influence of conditioning temperature on the postpellet recovery and efficacy of 2 microbial phytases for broiler chicks. J. Appl. Poult. Res. 22:308-313.

40. Inborr, J. and M. R. Bedford. 1994. Stability of feed enzymes to steam pelleting during feed processing. Anim. Feed Sci. Technol. 46:179-196.

41. Silversides, F. G., M. R. Bedford. 1999. Effect of pelleting temperature on the recovery and efficacy of a xylanase enzyme in wheat-based diets. Poult. Sci. 78:11841190. 


\section{TABLES AND FIGURES}

Table 1. Dietary composition and calculated nutrients of the basal diet used for inoculation.

\begin{tabular}{lc}
\hline \multicolumn{1}{c}{ Ingredient } & Inclusion (\%) \\
\hline Corn & 57.52 \\
Soybean Meal (48\%) & 30.82 \\
Wheat Middlings & 5.00 \\
Soybean Oil & 2.18 \\
Dicalcium Phosphate & 1.68 \\
Limestone & 1.31 \\
DL-Methionine & 0.36 \\
Salt & 0.35 \\
L-Lysine HCL & 0.27 \\
Vitamin/Mineral Premix ${ }^{1}$ & 0.25 \\
Sodium Bicarbonate & 0.15 \\
Threonine & 0.12 \\
\hline Calculated Nutrients & \\
\hline ME (kcal/kg) & $3,030.5$ \\
Crude Protein (\%) & 20.71 \\
Digestible Lysine (\%) & 1.18 \\
Digestible Met+Cys $(\%)$ & 0.89 \\
Digestible Threonine (\%) & 0.77 \\
Calcium (\%) & 0.96 \\
Available Phosphorus (\%) & 0.45 \\
Sodium (\%) & 0.20 \\
\hline Suplicd $\%$ (\%) & \\
\hline
\end{tabular}

${ }^{1}$ Supplied per kilogram of diet: $0.02 \%$ manganese; $0.02 \%$ zinc; $0.01 \%$ iron; $0.0025 \%$ copper; $0.0003 \%$ iodine;

$0.00003 \%$ selenium; $0.69 \mathrm{mg}$ of folic acid; $386 \mathrm{mg}$ of choline; $6.61 \mathrm{mg}$ of riboflavin; $0.03 \mathrm{mg}$ of biotin; $1.38 \mathrm{mg}$ of vitamin B6; $27.56 \mathrm{mg}$ of niacin; $6.61 \mathrm{mg}$ of pantothenic acid; $2.20 \mathrm{mg}$ of thiamine; $0.83 \mathrm{mg}$ of menadione; $0.01 \mathrm{mg}$ of vitamin B12; 16.53 IU of vitamin E; 2,133 IU of vitamin D3; and 7,716 of vitamin A. 
Table 2. Pelleting Technique and Hygieniser Use on Feed Manufacturing Metrics and E. faecium 8459 mitigation.

\begin{tabular}{|c|c|c|c|c|c|c|c|c|c|c|}
\hline Run Type & $\begin{array}{c}\text { Goal } \\
\text { Conditioning } \\
\text { Temperature } \\
\left({ }^{\circ} \mathrm{C}\right)\end{array}$ & $\begin{array}{c}\text { Conditioning } \\
\text { Time (sec) }\end{array}$ & $\begin{array}{c}\text { Hygieniser } \\
\text { (On/Off) }\end{array}$ & $\begin{array}{c}\text { Recorded } \\
\text { Conditioning } \\
\text { Temperature } \\
\left({ }^{\circ} \mathrm{C}\right)\end{array}$ & $\begin{array}{c}\text { Recorded } \\
\text { Hygieniser } \\
\text { Temperature } \\
\left({ }^{\circ} \mathrm{C}\right)\end{array}$ & $\begin{array}{c}\text { Motor } \\
\text { Load }^{1} \\
(\%)\end{array}$ & $\begin{array}{c}\text { Hot Pellet } \\
\text { Temperature }^{2} \\
\left({ }^{\circ} \mathrm{C}\right)\end{array}$ & $\begin{array}{c}\text { New Holman } \\
\text { Pellet Tester } \\
\text { Survivability } \\
\text { (\%) }\end{array}$ & $\begin{array}{c}\text { E. faecium } \\
\text { Mitigation }^{4} \\
\text { (Colonies) }\end{array}$ & $\begin{array}{c}\text { Relative } \\
\text { Reduction }^{5}(\%)\end{array}$ \\
\hline Mash & - & - & - & - & - & - & - & - & $88389.0^{\mathrm{a}}$ & - \\
\hline Standard & 70 & 15 & Off & 70.0 & 55.4 & 51.0 & 70.8 & 68.7 & $2822.3^{\mathrm{b}}$ & 99.97 \\
\hline More Thermally Aggressive & 80 & 30 & On & 80.2 & 82.8 & 44.0 & 79.7 & 89.7 & $320.0^{c}$ & 99.99 \\
\hline Anova P-value & - & - & - & 0.0003 & 0.0036 & 0.0198 & 0.0209 & 0.0692 & $<.0001$ & .0529 \\
\hline SEM $^{6}$ & - & - & - & 0.132 & 1.16 & 0.707 & 0.928 & 3.54 & 327.4 & 0.005 \\
\hline Fisher's LSD ${ }^{7}$ & - & - & - & - & - & - & - & - & 1285.6 & - \\
\hline
\end{tabular}

${ }^{1}$ A $100 \%$ motor load was based on FLA (full load amps) that was 47 amps based on the pellet mill motor name plate.

${ }^{2}$ Hot pellet temperature was determined on pellets directly following extrusion from the die. Pellets were collected into an insulated container and temperature was measured using a thermocouple thermometer and an 80PK-24 temperature probe.

${ }^{3}$ Measurements of PDI were obtained using the New Holmen Pellet Tester, where $100 \mathrm{~g}$ pelleted samples are subjected to air flow within a perforated chamber for $30 \mathrm{~s}$.

${ }^{4}$ E. faecium mitigation $=$ Determined using serial dilutions, vacuum filtration, bacteria specific m-ENT media, and incubation. Pink colonies were counted following $35^{\circ} \mathrm{C}$ incubation for 48 hours.

${ }^{5}$ Relative Reduction $=100$ - (Pellet Colony Count/Mash Colony Count $)$

${ }^{6} \mathrm{SEM}=$ Pooled Standard error of the mean.

${ }^{7}$ Fisher's least significant difference value 
The Effect of Varying Steam Conditioning Temperature and Time on Pellet Manufacture Variables, Digestible Amino Acid Concentration, and Feed Enzyme Recovery

T. P. Boltz ${ }^{1}$, N. E. Ward ${ }^{2}$, V. E. Ayres ${ }^{1}$, A. E. Lamp ${ }^{1}$ and J. S. Moritz ${ }^{1}$

${ }^{1}$ Division of Animal and Nutritional Science, West Virginia University, Morgantown, West

Virginia, 26506

Phone: 304-293-1911

Fax: 304-293-2232

${ }^{2}$ DSM Nutritional Products Inc., Parsippany, NJ 07054

Phone: +1-973-257-8500 


\section{SUMMARY}

This study hypothesized that increased steam conditioning temperature and conditioning time would improve feed manufacture metrics while decreasing the digestible amino acid concentration and recovery of a lysozyme feed additive. The objectives of the study were to assess how varying steam conditioning temperatures and conditioning times interacted to affect pellet mill motor load, pellet quality, digestible amino acid concentration, and enzyme recovery. Corn and soybean meal based diets that included DDGS and meat and bone meal were conditioned at either $76^{\circ} \mathrm{C}, 82^{\circ} \mathrm{C}$, or $88^{\circ} \mathrm{C}$ with conditioning times of either 30 or 60 seconds. Treatments were arranged in a 3 (steam conditioning temperature) $\times 2$ (conditioning time) factorial in a randomized complete block design. Digestible amino acid concentration was estimated using cececotomized roosters in a Latin Square with crossover design. Motor load decreased for 30 second conditioning compared to 60 second conditioning when diets were subjected to 76 and $82^{\circ} \mathrm{C}$, but the time effect was lost at $88^{\circ} \mathrm{C}$. This interaction was likely the result of lower feed volume in the conditioner as per 30 second conditioning obtaining greater moisture condensation and lubrication at lower conditioning temperatures. Lysozyme activity decreased when conditioned at $88^{\circ} \mathrm{C}(\mathrm{P}=0.0001)$, but was not affected by retention time. Conditioning temperature and time interacted to affect digestible amino acid concentrations of methionine, lysine, threonine, alanine, aspartic acid, glutamic acid, isoleucine, leucine, proline, and valine $(\mathrm{P}<0.05)$. Increased conditioning temperatures at 30 seconds increased digestible amino acid concentrations. Similarly, diets conditioned at 60 seconds increased digestible amino acid concentration between 76 and $82^{\circ} \mathrm{C}$.

Key words: Conditioning, Pelleting, Amino Acid, Digestibility, Enzyme 


\section{DESCRIPTION OF PROBLEM}

Commercial broiler production relies on pelleting as it has been shown to decrease feed wastage, ingredient segregation, prehensile energy expenditure, selective feeding, and reduce pathogen mitigation [1]. Due to increased regulation on feed safety and the desire to reduce pathogens as well as a desire for improved pellet quality, higher conditioning temperatures and longer conditioning times are being utilized in pelleted feed manufacture. The use of more thermally aggressive conditioning techniques may be a concern for nutrient availability. Use of high temperatures over $85^{\circ} \mathrm{C}$ have been shown to significantly reduce digestibility of amino acids such as methionine and valine [2-3]. Vitamins are also susceptible to heat as demonstrated that pelleting at $93^{\circ} \mathrm{C}$ decreased vitamin A by $6.7 \%$ [4]. Along with amino acids being negativity impacted by higher temperatures, exogenous enzymes can also become denatured and negatively affect bird performance [5-6].

Positive benefits of increased conditioning temperature could be improved pellet quality, which in turn could improve bird performance. It has been well documented that having an improved pellet-to-fine ratio allows broilers to have improved performance and decreased feed conversation ratios [7-9]. More specially, modest improvements in pellet quality from $50 \%$ crumble/pellet to $70 \%$ may improve broiler performance and decreased feed conversation ratio by 3 points [7]. Increased steam conditioning temperature results in a higher amount of moisture being added to the mash feed which can improve pellet quality [10]. Increased conditioning time (60 sec vs $30 \mathrm{sec}$ ) has also been shown to increase pellet durability [11].

Use of cecectomized roosters is a common and reliable method for determining nutrient digestibility. Cecectomized roosters are better models for estimating amino acid digestibility than conventional roosters as removal of the ceca reduces microbial activity in the hind-gut [12]. In addition, cecectomized roosters are commonly used for determination of amino acid digestibility 
due to the relatively simple surgical procedure, easy maintenance, and no need for digesta markers [13].

More pressure from markets worldwide have seen a decrease in antibiotic use in animal feeds. One alternative that has been investigated are lysozymes. Lysozyme are naturally occurring enzymes that are found in tears, salvia, and milk and are also used in feed. Lysozymes cleave glyosidic linkages in the peptidoglycan components of bacterial cell walls which lead to loss of cellular membrane integrity and ultimately cell death [14]. Feeding this enzyme to swine has shown decreased Campylobacter prevalence in the digestive tract and increased growth rates, while in poultry reduced numbers of $E$. coli were reported when compared to birds being fed a diet with an antibiotic [14-16].

The objective of the current study was to access how varying steam conditioning temperatures and conditioning times interacted to affect feed manufacture metrics, amino acid digestibility using single comb white leghorn cecectomized roosters, and enzyme recovery.

\section{MATERIALS AND METHODS}

\section{Diet Formulation and Batching}

A corn and soybean basal diet with DDGS and meat and bone meal was formulated to meet industry specifications for nutritional needs of growing broiler chickens. Soybean meal sent to a commercial laboratory to be analyzed for trypsin inhibitor which was reported to be $3.64 \mathrm{TIU} / \mathrm{mg}$ [17]. One master batch of basal diet, $3,266.1 \mathrm{~kg}$, was manufactured and separated into three replications of $1,088.7 \mathrm{~kg}$. From each replication, six allotments of $362.9 \mathrm{~kg}$ were used for the varying conditioning temperatures $\left(76^{\circ} \mathrm{C}, 82^{\circ} \mathrm{C}, 88^{\circ} \mathrm{C}\right)$ and conditioning time $(30$ and 60 seconds), creating a total of six experimental diets. A lysozyme product was added to all diets to determine the thermostability of the enzyme. 


\section{Feed Manufacture}

All feed was manufactured at the West Virginia University pilot feed mill located in Morgantown, West Virginia. A California Pellet mill conditioner, hygieniser and 40 HP pellet mill [18] was used for pelleting and pellets were extruded through a 4.7 x $38 \mathrm{~mm}$ pellet die. Production rate was constant at $1.2 \mathrm{MT} / \mathrm{hr}$ among all replications of manufacture. For this experiment the hygieniser was not on and so no heated retention of feed occurred. Feed still passed through the hygieniser as there is no way to bypass it within this feed manufacture system. Conditioner, hygieniser temperature, and pellet mill motor amperage were recorded using a Beta Raven programmable logic control (PLC) [19] system after goal temperature had been achieved for each treatment. Pellet samples were taken directly after pellet die extrusion and placed on a cheesecloth on top of a large agriculture fan that pulled ambient air across the pellets for a standardized time of 12 minutes to allow the pellets to cool and dry. This follows methodologies from Reese et al. [20], that limits potential nutrient segregation effects of post pellet auguring. In addition, a portion of the pelleted samples was assayed for hot pellet temperature using an insulated container to catch pellets and then immediately closing the lid, inserting a thermocouple [21] with an 80PK-24 temperature probe.

\section{Pellet Quality Analysis}

24 hours post-pelleting, pellet quality was determined utilizing a New Holman pellet tester (NHPT) [22]. All pelleted samples from each treatment were sifted using a NO. 6 W.S. Tyler testing sieve [23]. One hundred gram samples of sifted pellets were placed in the NHPT perforated chamber, where forced air was applied for 30 seconds and the remaining pellet samples were weighed and recorded as a percentage. Pellet quality analyses were conducted in triplicate for each treatment and results reflect average pellet durability. 


\section{True Amino Acid Digestibility (TAAD)}

Dietary treatments were precision fed to six, 18-month-old cecectomized Single Comb White Leghorn (SCWL) roosters for determination of TAAD. This was done using a Latin Square with crossover design where each rooster was fed all six of the experimental diets over a 14-week period in a way that no two roosters were fed the same diet during the same week. A wash out period of one week was utilized between precision feedings to ensure birds did not have residual diet. Corn starch pellets were precision fed to each rooster during the last week to determine endogenous amino acid losses. Precision feeding followed modified methodologies of Sibbald [24], where SCWL roosters were fasted for 24 hours and then precision fed 30 grams of sample directly into the crop. Excreta was collected for 48 hours post feeding. Amino acid analysis on feed and excreta were conducted by a commercial laboratory [25]. The following equations was used to calculate the true amino acid digestibility and then amino acid concentration:

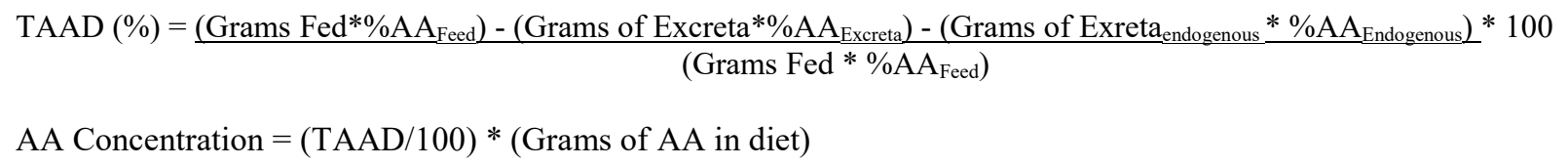

\section{Statistical Analysis}

Variables were analyzed in a 3 (conditioning temperature) x 2 (conditioning time) factorial arrangement in a randomized complete block design. The experimental unit consisted of one 362.9 $\mathrm{kg}$ batch of feed or one SCWL rooster. A multiple comparison was performed to compare main effect means. Digestible amino acid concentration was estimated using cececotomized roosters in a Latin Square with crossover design. The conditioning temperature and conditioning time interactions were further determined using Fisher's least significant difference test. Data was analyzed using the GLM procedure of SAS [26] and alpha was designed to be $\mathrm{P} \leq 0.05$. 


\section{RESULTS AND DISCUSSION}

The basal diet formulation can be found in Table 1. Feed manufacture and pellet quality main effect and interaction data are presented in Table 2. Conditioning temperature and conditioning time interacted in their effect on motor load $(\mathrm{P}=0.0168)$ and hot pellet temperature $(\mathrm{P}=0.0477)$. This interaction was likely the result of lower feed volume in the conditioner as per 30 second conditioning obtaining greater moisture condensation and lubrication at lower conditioning temperatures. Conditioning time had a greater influence on motor load at low conditioning temperatures, where a longer retention time increased motor load. Increasing conditioning temperature decreased motor load and conditioning time had no effect at high conditioning temperatures. This effect is most likely due to gelatinization of ingredients, which lead to a more viscous diet. The increased volume of feed to steam ratio provided more moisture to the diet, which added extra lubrication at the die which resulted in decreased motor load [3, 2729]. Boney and Moritz found that as conditioning temperature increased, so did hot pellet temperature [3]. As conditioning temperature and time was increased so did hygieniser temperature, which could have contributed to the interaction for hot pellet temperature. The varying feed volume to steam ratio could affected the hot pellet temperatures as the shorter retention time had a lower feed volume allowing the steam to penetrate further into the mash feed which raised the overall temperature of the feed.

Conditioning temperature affected all metric measured except for motor load and hot pellet temperature variables measured. Conditioning temperature $(\mathrm{P}=0.0001)$ and hygieniser temperature $(\mathrm{P}=0.0011)$ increased with increasing steam conditioning temperature, which is by design. New Holman Test results improved with increasing temperature $(\mathrm{P}=0.0005)$. Past literature has demonstrated that increased conditioning temperature improves pellet quality, which was observed 
in this study with a 24.8 percentage point difference between $77^{\circ} \mathrm{C}$ and $88^{\circ} \mathrm{C}$ treatments $[3-4,27$, 29]. The additional moisture added during the heating process could aid in starch gelatinization and improved protein denaturation, which would result in improved pellet quality [30-31].

Conditioning time affected hygieniser temperature $(\mathrm{P}=0.0435)$. The hygieniser was turned off for this experiment, but conditioned feed still had to pass through it before being pelleted. The feed volume to steam ratio for the different times is what caused a difference in the temperature the hygieniser was displaying on the PLC. The lower feed volume for the 30 second treatment allowed heat to penetrate the mash feed and concentrate in the center of the mash. This allowed for the hygieniser to be heated more when feed passed through it when compared to the 60 second treatments as the heat could not penetrate the mash feed as deep.

Conditioning temperature and conditioning time interacted their effect on all measured amino acids, other than cysteine and glycine (Table 3). Interactions for the 3 most limiting essential amino acids (Lys, Met, and Thr) are shown in Figures 1-3. These interactions are most likely due to the extended conditioning time and increased conditioning temperature having positive effects on anti-nutritional factors that were in the diet. Trypsin inhibitor was high in this diet at $3.64 \mathrm{TIU} / \mathrm{mg}$, which is above the industry standards of $<0.2$ to 3.5 [32]. Past research has shown that diets containing $1.46 \mathrm{TIU} / \mathrm{mg}$ can have negative effects on the performance of nonruminant animals [33]. In the current study conditioning at 30 seconds for 77,82 , and $88^{\circ} \mathrm{C}$ and 60 seconds at 77 and $82^{\circ} \mathrm{C}$ demonstrated to increase digestibility when compared to $88^{\circ} \mathrm{C}$ for 60 seconds. Bergeron et al. speculated that thermal processing can affect the cell wall of feed ingredients by breaking down the aleurone layer, which can lead to increased opportunities for nutrient utilization [34]. 
Proteins in the diet could have undergone gelation, which is the aggregation of denatured molecules with a certain degree of order, resulting in the formation of a continuous network [35]. Before gelation can occur, proteins must first be denatured and then heat and moisture are added to initiate the gelation process [36]. Proteins in the feed could have been denatured and gelled to point that was still available to the birds when conditioned at 76,82 , and $88^{\circ} \mathrm{C}$ for 30 seconds and 72 and $82^{\circ} \mathrm{C}$ for 60 seconds, but not when conditioned at $88^{\circ} \mathrm{C}$ for 60 seconds. The addition moisture and heat required for the $88^{\circ} \mathrm{C}$ treatment may have led to a greater proportion of gelation of proteins in the diet, which resulted in less amino acids being available to the bird.

Lysozyme retention decreased with conditioning temperature $(\mathrm{P}=0.0001)$, but was not affected by conditioning time. Similar recovery was observed for the $77^{\circ} \mathrm{C}$ and $82^{\circ} \mathrm{C}$ treatments, but a significant drop in recovery was observed for the $88^{\circ} \mathrm{C}$ treatment. These results suggest that conditioning time does not affect the thermostability of an enzyme, but the temperature at which the feed is processed does. Past literature has shown that increased conditioning temperatures denature enzymes, which is in agreement with results from this study [37].

\section{CONCLUSION AND APPLICATIONS}

1. Increasing conditioning temperature and time decreased pellet mill motor load.

2. Increasing conditioning time does not affect exogenous enzyme recovery. However conditioning temperature of $88^{\circ} \mathrm{C}$ decreased recovery.

3. Conditioning broiler diets at $88^{\circ} \mathrm{C}$ for 60 seconds demonstrated a decrease in digestible amino acid concentration when the same diets were conditioning at 77,82 and $88^{\circ} \mathrm{C}$ for 30 second and 76 and $82^{\circ} \mathrm{C}$ for 60 seconds. 


\section{REFERENCES AND NOTES}

1. Behnke, K.C. 1994. Factors affecting pellet quality. Proc. Maryland Nutrition Conference. 20-25 March 1994. Department of Poultry Science and Animal Science, College of Agriculture, University of Maryland, College Park.

2. Loar II, R. E., K. G. S. Wamsley, A. Evans, J. S. Moritz, and A. Corzo. 2014. Effects of varying conditioning temperature and mixer-added fat on feed manufacturing efficiency, 28- to 42-day broiler performance. Early skeletal effect, and true amino acid digestibility. J. Appl. Poult. Res. 23:444-455.

3. Boney, J. W. and J. S. Moritz. 2017. The effects of Spirulina algae inclusion and conditioning temperature on feed manufacture, pellet quality, and true amino acid digestibility. Anim. Feed Sci. Technol. 224:20-29.

4. Cutlip, S. E., J. M. Hott, N. P. Buchanan, A. L. Rack, J. D. Latshaw, and J. S. Mortiz. 2008. The Effect of Steam-Conditioning Practices on Pellet Quality and Growing Broiler Nutritional Value. J. Appl. Poult. Res. 17:249-261.

5. Gehring, C. K., K. G. S. Lilly, L. K. Shires, K. R. Beaman, S. A. Loop, and J. S. Moritz. 2011. Increasing mixer-added fat reduces the electrical energy required for pelleting and improves exogenous enzyme efficacy for broiler. J. Appl. Poult. Res. 20:75-89.

6. Silversides, F. G., M. R. Bedford. 1999. Effect of pelleting temperature on the recovery and efficacy of a xylanase enzyme in wheat-based diets. Poult. Sci. 78:1184-1190.

7. Glover, B. G., K. L. Foltz, I. Holásková, and J. S. Moritz. 2015. Effects of modest improvements in pellet quality and experiment pen size on broiler chicken performance. J. Appl. Poult. Res. 25:21-28.

8. Lemons, M. E. and J. S. Moritz. 2015. The effect of feeder space access and crumble- or pellet-to-fine ratio on 38-day-old broiler performance. J. Appl. Poult. Res. 25:12-20.

9. Scheideler, S. E. 1991. Pelleting is important to broilers. Proc. of the Carolina Poultry Nutrition Conf. Caroline Feed Industry Association. Sanford, NC.

10. Buchanan, N. P., K. G. S. Lilly, C. K. Gehring, and J.S. Moritz. 2010. The effects of altering diet formulation and manufacturing technique on pellet quality. J. Appl. Poult. Res. 19:112-120.

11. Boney, J. W., J. Jaczynski, J. L. Weidhaas, A. N. Bergeron, and J. S. Moritz. 2018. The effects of steam conditioning and antimicrobial inclusion on feed manufacture and inactivation of Enterococcus faecium, a Salmonella surrogate. J. Appl. Poult. Res. 0:1-11.

12. Parsons, C. M. 1986. Determination of digestible and available amino acids in meat meal using conventional and caecetomized cockerels or chick assays. Brit. J. of Nut. 56:227240.

13. Parsons, C. M. 1985. Influence of caecectomy on digestibility of amino acids by roosters fed distillers' dried grains with solubles. J. agric. Sci. 104:469-472.

14. Ellison, R. T and T. J. Giehl. 1991. Killing of gram-negative bacteria by lactoferrin and lysozyme. J Clin Invest. 88:1080-91.

15. Oliver, W. and J. Wells. 2014. Lysozyme as alternative to antibiotics in swine. AllAboutFeed 22. 
16. Gong, M., D. Anderson, B. Rathgeber, and J. MacIsaac. 2016. The effect of dieaty lysozyme with EDTA on growth performance and intestinal microbiota of broiler chickens in each period of the growth cycle. J. Appl. Poult. Res. 26:1-8.

17. NP Analytical Laboratories. St. Louis, MO.

18. Master Model Pellet Mill, California Pellet Mill Company, Crawfordsville, IN.

19. Beta Raven Automation Solutions, St. Charles, MO.

20. Reese, D. A., K. L. Foltz, and J. S. Moritz. 2017. Effect of mixing and sampling method on pelleted feed nutrient analysis and diet formulation validation. J. Appl. Poult. Res. 26:219-225.

21. Fluke 51 II, Everette, WA.

22. New Holmen Portable Pellet Durability Tester, Lignotech USA Inc., Rothschild, WI.

23. U.S.A Standard Test Sieve. No. 6. W.S. Tyler. Mentor, OH.

24. Sibbald, I. R. 1976. A bioassay for true metabolizable energy in feedingstuffs. Poult. Sci. 55:303-308. Feed was withheld for $24 \mathrm{~h}$, approximately $30 \mathrm{~g}$ of feed were precision fed, and excreta was collected for $48 \mathrm{~h}$.

25. Agricultural Experiment Station Chemical Laboratories. Columbia, MO.

26. SAS Institute. 2017. The SAS System for Windows 2017. Release 9.4 SAS Inst. Inc., Cary, NC.

27. Lilly, K. G. S., C. K. Gehring, K. R. Beaman, P. J. Turk, M. Sperow, and J. S. Moritz. 2011. Examining the relationships between pellet quality, broiler performance, and bird sex, J. Appl. Poult. Res. 20:231-239.

28. Moritz, J. S., K. R. Cramer, K. J. Wilson, and R. S. Beyer. 2003. Feed manufacture and feeding of rations with graded levels of added moisture formulated to different energy densities. J. Appl. Poult. Res. 12:371-381.

29. Corey, A. M., K. G. S. Wamsley, T. S. Winowiski, and J. S. Moritz. 2014. Effects of calcium lignosulfonate, mixer-added fat, and feed form on feed manufacture and broiler performance. J. Appl. Poult. Res. 23:418-428.

30. Moritz, J. S., R. S. Beyer, K. J. Wilson, and K. R. Cramer. 2001. Effect of moisture at the mixer to a corn-soybean-based diet on broiler performance. J. Appl. Poult. Res. 10:347353.

31. Moritz, J. S., K. J. Wilson, K. R. Cramer, R. S. Beyer, L. J. McKinney, W. B. Cavalcanti, and X. Mo. 2002. Effect of formulation density, moisture, and surfactant on feed manufacturing, pellet quality, and broiler performance. J. Appl. Poult. Res. 11:155-16.

32. Ruiz, N., F. Belalcázar, and J. Castillo. 2018. Field observations: Neither KOH protein solubility nor urease activity are adequate quality predictors of commercial full-fat soybeans for poultry. Page 311 in Poultry Science Association 107 ${ }^{\text {th }}$ Annual Meeting, San Antonio, TX.

33. Hong, K. J., C. H. Lee, and S. W. Kim. 2004. Aspergillus oryzae GB-107 fermentation improves nutritional quality of food soybeans and feed soybean meals. J. Med. Food. 7:430-435.

34. Bergeron, A. N., J. W. Boney, and J. S. Moritz. The effects of diet formulation and thermal processes associated with pelleting on 18-day broiler performance and digestible amino acid concentration. J. Appl. Poult. Res. 27:540-549. 
35. Wong, D.W.S. 1989. Mechanism and Theory in Food Chemistry. Pages 48-62. New York: Avi/Van Nostrand Reinhold.

36. Jaczynski, J. 2019. West Virginia University. Personal communication.

37. Beaman, K. R., K. G. S. Lilly, C. K. Gehring, P. J. Turk, and J. S. Moritz. 2010. Influence of pelleting on the efficacy of an exogenous enzyme cocktail using broiler performance and metabolism. J. Appl. Poult. Res. 21:744-756. 


\section{TABLES AND FIGURES}

Table 1. Dietary composition and calculated nutrients of the basal diet.

\begin{tabular}{cc}
\hline Ingredients & \% in Diet \\
\hline Corn & 52.31 \\
Soybean Meal $(46 \%)^{1}$ & 35.13 \\
Soybean Oil & 3.40 \\
DDGS & 3.00 \\
Meat and Bone Meal & 2.61 \\
Limestone & 1.38 \\
DiCalcium Phosphate & 0.65 \\
Methionine & 0.48 \\
Threonine & 0.29 \\
Vitamin/Mineral Premix & 0.25 \\
Salt & 0.25 \\
Lysine & 0.14 \\
Sodium Bicarbonate & 0.10 \\
\hline
\end{tabular}

\section{Calculated Nutrients}

\begin{tabular}{cc}
\hline ME (kcal/kg) & 3,000 \\
Crude Protein (\%) & 23.00 \\
Calcium (\%) & 1.01 \\
Available Phosphorus (\%) & 0.36 \\
Sodium (\%) & 0.14 \\
Lysine (\%) & 1.20 \\
Methionine (\%) & 0.79 \\
Methionine + Cysteine (\%) & 1.08 \\
Threonine (\%) & 1.01 \\
Tryptophan (\%) & 0.23 \\
\hline
\end{tabular}

${ }^{1}$ Trypsin inhibitor was analyzed and determined to be $3.64 \mathrm{TIU} / \mathrm{mg}$, where TIU is Trypsin Inhibitor Units.

${ }^{2}$ Supplied per kilogram of diet: $0.02 \%$ manganese; $0.02 \%$ zinc; $0.01 \%$ iron; $0.0025 \%$ copper; $0.0003 \%$ iodine; $0.00003 \%$ selenium; $0.69 \mathrm{mg}$ of folic acid; $386 \mathrm{mg}$ of choline; $6.61 \mathrm{mg}$ of riboflavin; $0.03 \mathrm{mg}$ of biotin; $1.38 \mathrm{mg}$ of vitamin B6; $27.56 \mathrm{mg}$ of niacin; $6.61 \mathrm{mg}$ of pantothenic acid; $2.20 \mathrm{mg}$ of thiamine; $0.83 \mathrm{mg}$ of menadione; $0.01 \mathrm{mg}$ of vitamin B12; $16.53 \mathrm{IU}$ of vitamin E; 2,133 IU of vitamin D3; and 7,716 of vitamin A. 
Table 2. The effects of conditioning temperature and conditioning time on feed manufacture variables and pellet quality.

\begin{tabular}{|c|c|c|c|c|c|c|c|}
\hline Conditioning Temperature $\left({ }^{\circ} \mathrm{C}\right)$ & $\begin{array}{l}\text { Conditioning } \\
\text { Time }(\mathrm{sec})\end{array}$ & $\begin{array}{l}\mathrm{NHPT}^{1} \\
(\%)\end{array}$ & $\begin{array}{c}\text { Conditioner } \\
\text { Temperature }^{2} \\
\left({ }^{\circ} \mathrm{C}\right) \\
\end{array}$ & $\begin{array}{c}\text { Hygieniser } \\
\text { Temperature } \\
\left({ }^{\circ} \mathrm{C}\right) \\
\end{array}$ & $\begin{array}{l}\text { Motor Load } \\
(\%)\end{array}$ & $\begin{array}{c}\text { Hot Pellet } \\
\text { Temperature } \\
\left({ }^{\circ} \mathrm{C}\right) \\
\end{array}$ & $\begin{array}{c}\text { Muramidase } \\
\text { Activity } \\
(\mathrm{LSU}(\mathrm{F}) / \mathrm{kg}) \\
\end{array}$ \\
\hline 77 & 30 & 47.3 & 77.0 & 66.7 & $41.7^{\mathrm{b}}$ & $77.5^{\mathrm{c}}$ & $24,900.8$ \\
\hline 82 & 30 & 61.3 & 81.9 & 70.7 & $39.7^{\mathrm{c}}$ & $81.0^{\mathrm{b}}$ & $25,260.0$ \\
\hline 88 & 30 & 68.7 & 85.6 & 76.3 & $39.3^{c}$ & $86.2^{\mathrm{a}}$ & $19,216.3$ \\
\hline 77 & 60 & 44.0 & 76.7 & 62.8 & $44.7^{\mathrm{a}}$ & $75.4^{\mathrm{d}}$ & $25,938.0$ \\
\hline 82 & 60 & 59.0 & 82.0 & 67.8 & $41.3^{b}$ & $80.6^{\mathrm{b}}$ & $23,925.3$ \\
\hline 88 & 60 & 72.3 & 87.6 & 72.8 & $39.7^{\mathrm{c}}$ & $86.8^{\mathrm{a}}$ & $16,739.1$ \\
\hline Treatment $P$-Value & --- & 0.0037 & $<0.0001$ & 0.0051 & $<0.0001$ & $<0.0001$ & $<0.0001$ \\
\hline Treatment SEM ${ }^{7}$ & --- & 4.14 & 0.649 & 1.83 & 0.375 & 0.490 & $1,269.8$ \\
\hline \multicolumn{8}{|c|}{ Conditioning Temperature } \\
\hline 77 & --- & $45.7^{\mathrm{c}}$ & $76.9^{\mathrm{c}}$ & $64.7^{c}$ & $43.2^{\mathrm{a}}$ & $76.5^{\mathrm{c}}$ & $25,419.4^{\mathrm{a}}$ \\
\hline 82 & --- & $60.2^{\mathrm{b}}$ & $81.9^{\mathrm{b}}$ & $69.3^{b}$ & $40.5^{b}$ & $80.8^{b}$ & $24,592.7^{\mathrm{a}}$ \\
\hline 88 & --- & $70.5^{\mathrm{a}}$ & $86.6^{\mathrm{a}}$ & $74.5^{\mathrm{a}}$ & $39.5^{\mathrm{c}}$ & $86.5^{\mathrm{a}}$ & $17,977.7^{\mathrm{b}}$ \\
\hline Conditioning Temperature SEM & --- & 2.93 & 0.459 & 1.30 & 0.265 & 0.347 & 943.7 \\
\hline \multicolumn{8}{|c|}{ Conditioning Time } \\
\hline--- & 30 & 59.1 & 81.5 & $71.2^{\mathrm{a}}$ & $40.2^{\mathrm{b}}$ & 81.6 & $23,287.1$ \\
\hline--- & 60 & 58.4 & 82.1 & $67.8^{\mathrm{b}}$ & $41.9^{\mathrm{a}}$ & 80.9 & $22,447.2$ \\
\hline Conditioning Time SEM & --- & 2.39 & 0.374 & 1.06 & 0.217 & 0.283 & 802.0 \\
\hline \multicolumn{8}{|c|}{ Probability Values } \\
\hline Conditioning Temperature & --- & 0.0005 & $<0.0001$ & 0.0011 & $<0.0001$ & $<0.0001$ & $<0.0001$ \\
\hline Conditioning Time & --- & 0.8476 & 0.2708 & 0.0435 & 0.0003 & 0.1433 & 0.3611 \\
\hline $\begin{array}{c}\text { Conditioning Temperature by } \\
\text { Conditioning Time }\end{array}$ & --- & 0.6691 & 0.2015 & 0.9683 & 0.0168 & 0.0477 & 0.3984 \\
\hline
\end{tabular}

${ }^{1}$ Durability was measured using the New Holmen Pellet Tester are where 100 gram pelleted samples are subjected to air flow within a perforated chamber for 30 seconds.

${ }^{2}$ Conditioning temperature was measured as the reading from the conditioner temperature probe at the time of sample collection.

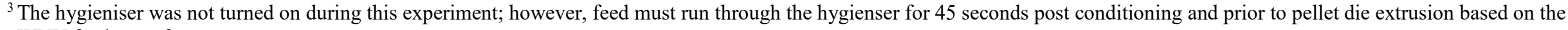
WVU feed manufacture system.

${ }^{4}$ A $100 \%$ motor load was based on FLA (full load amps) that was 47 amps based on the pellet mill motor name plate.

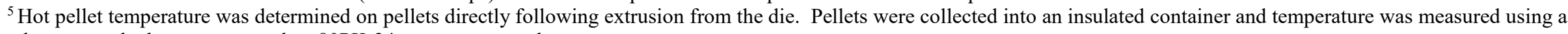
thermocouple thermometer and an 80PK-24 temperature probe.

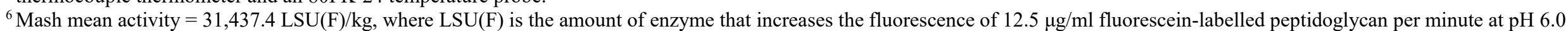
and $30{ }^{\circ} \mathrm{C}$ by a value that corresponds to the fluorescence of approximately $0.06 \mathrm{nmol}$ fluorescein isothiocyanate isomer.

${ }^{7}$ SEM: Pooled Standard error of the mean.

${ }^{\mathrm{a}-\mathrm{c}}$ Means within a column not sharing a common superscript differ significantly $(P<0.05)$. 
Table 3. The effects of conditioning temperature and conditioning time on Digestible Amino Acid Concentration.

\begin{tabular}{|c|c|c|c|c|c|c|c|c|c|c|c|c|c|}
\hline $\begin{array}{l}\text { Conditioning Temperature } \\
\qquad\left({ }^{\circ} \mathrm{C}\right)\end{array}$ & $\begin{array}{l}\text { Conditioning } \\
\text { Time }(\mathrm{sec})\end{array}$ & $\begin{array}{l}\text { Alanine } \\
(\%)\end{array}$ & $\begin{array}{l}\text { Aspartic } \\
\text { Acid }(\%)\end{array}$ & $\begin{array}{c}\text { Cysteine } \\
(\%)\end{array}$ & $\begin{array}{l}\text { Glutamic } \\
\text { Acid }(\%)\end{array}$ & $\begin{array}{l}\text { Glycine } \\
(\%)\end{array}$ & $\begin{array}{l}\text { Isoleucine } \\
(\%)\end{array}$ & $\begin{array}{l}\text { Leucine } \\
(\%)\end{array}$ & $\begin{array}{l}\text { Lysine } \\
(\%)\end{array}$ & $\begin{array}{l}\text { Methionine } \\
(\%)\end{array}$ & $\begin{array}{l}\text { Proline } \\
(\%)\end{array}$ & $\begin{array}{l}\text { Threonine } \\
(\%)\end{array}$ & $\begin{array}{l}\text { Valine } \\
(\%)\end{array}$ \\
\hline 77 & 30 & $1.02^{\mathrm{b}}$ & $2.31^{\mathrm{c}}$ & 0.29 & $3.64^{\mathrm{d}}$ & 0.64 & $0.92^{\mathrm{cd}}$ & $1.76^{\mathrm{d}}$ & $1.31^{\mathrm{c}}$ & $0.73^{\mathrm{d}}$ & $1.46^{\mathrm{bc}}$ & $0.99^{\mathrm{c}}$ & $1.01^{\mathrm{c}}$ \\
\hline 82 & 30 & $1.08^{\mathrm{a}}$ & $2.47^{\mathrm{a}}$ & 0.31 & $3.80^{\mathrm{b}}$ & 0.69 & $0.98^{\mathrm{a}}$ & $1.83^{\mathrm{b}}$ & $1.40^{\mathrm{a}}$ & $0.74^{\mathrm{c}}$ & $1.49^{\mathrm{a}}$ & $1.04^{\mathrm{b}}$ & $1.09^{\mathrm{a}}$ \\
\hline 88 & 30 & $1.09^{\mathrm{a}}$ & $2.46^{\mathrm{a}}$ & 0.31 & $3.90^{\mathrm{a}}$ & 0.69 & $0.99^{\mathrm{a}}$ & $1.87^{\mathrm{a}}$ & $1.40^{\mathrm{a}}$ & $0.80^{\mathrm{b}}$ & $1.49^{\mathrm{a}}$ & $1.07^{\mathrm{a}}$ & $1.08^{\mathrm{a}}$ \\
\hline 77 & 60 & $1.03^{\mathrm{b}}$ & $2.35^{\mathrm{b}}$ & 0.30 & $3.74^{\mathrm{c}}$ & 0.62 & $0.93^{\mathrm{c}}$ & $1.81^{\mathrm{bc}}$ & $1.32^{\mathrm{c}}$ & $0.74^{\mathrm{c}}$ & $1.48^{\mathrm{ab}}$ & $1.02^{\mathrm{c}}$ & $1.02^{\mathrm{c}}$ \\
\hline 82 & 60 & $1.04^{\mathrm{b}}$ & $2.39^{\mathrm{b}}$ & 0.30 & $3.74^{\mathrm{c}}$ & 0.65 & $0.95^{\mathrm{b}}$ & $1.79^{\mathrm{c}}$ & $1.36^{\mathrm{b}}$ & $0.81^{\mathrm{a}}$ & $1.45^{\mathrm{c}}$ & $1.05^{\mathrm{b}}$ & $1.05^{\mathrm{b}}$ \\
\hline 88 & 60 & $1.03^{\mathrm{b}}$ & $2.31^{\mathrm{c}}$ & 0.29 & $3.64^{\mathrm{d}}$ & 0.61 & $0.91^{\mathrm{d}}$ & $1.75^{\mathrm{d}}$ & $1.32^{\mathrm{c}}$ & $0.72^{\mathrm{e}}$ & $1.44^{\mathrm{c}}$ & $1.01^{\mathrm{c}}$ & $1.01^{\mathrm{c}}$ \\
\hline Treatment P-Value & --- & $<0.0001$ & $<0.0001$ & 0.0617 & $<0.0001$ & 0.7753 & $<0.0001$ & $<0.0001$ & $<0.0001$ & $<0.0001$ & $<0.0001$ & $<0.0001$ & $<0.0001$ \\
\hline Treatment SEM ${ }^{1}$ & --- & 0.008 & 0.012 & 0.005 & 0.015 & 0.053 & 0.004 & 0.008 & 0.008 & 0.002 & 0.007 & 0.006 & 0.006 \\
\hline \multicolumn{14}{|c|}{ Conditioning Temperature } \\
\hline 77 & --- & $1.03^{b}$ & $2.33^{c}$ & 0.30 & $3.69^{b}$ & 0.63 & $0.92^{c}$ & $1.78^{b}$ & $1.32^{b}$ & $0.73^{c}$ & 1.47 & $1.00^{\mathrm{b}}$ & $1.02^{\mathrm{c}}$ \\
\hline 82 & --- & $1.06^{\mathrm{a}}$ & $2.43^{\mathrm{a}}$ & 0.31 & $3.77^{\mathrm{a}}$ & 0.67 & $0.97^{\mathrm{a}}$ & $1.81^{\mathrm{a}}$ & $1.38^{\mathrm{a}}$ & $0.77^{\mathrm{a}}$ & 1.47 & $1.05^{\mathrm{a}}$ & $1.07^{\mathrm{a}}$ \\
\hline 88 & --- & $1.06^{\mathrm{a}}$ & $2.39^{b}$ & 0.30 & $3.77^{\mathrm{a}}$ & 0.65 & $0.95^{\mathrm{b}}$ & $1.81^{\mathrm{a}}$ & $1.36^{\mathrm{a}}$ & $0.76^{\mathrm{b}}$ & 1.47 & $1.04^{\mathrm{a}}$ & $1.04^{\mathrm{b}}$ \\
\hline $\begin{array}{c}\text { Conditioning Temperature } \\
\text { SEM }\end{array}$ & --- & 0.005 & 0.008 & 0.004 & 0.011 & 0.037 & 0.003 & 0.005 & 0.006 & 0.001 & 0.005 & 0.005 & 0.005 \\
\hline \multicolumn{14}{|c|}{ Conditioning Time } \\
\hline--- & 30 & $1.06^{\mathrm{a}}$ & $2.41^{\mathrm{a}}$ & 0.30 & $3.78^{\mathrm{a}}$ & 0.68 & $0.96^{\mathrm{a}}$ & $1.82^{\mathrm{a}}$ & $1.37^{\mathrm{a}}$ & 0.75 & $1.48^{\mathrm{a}}$ & 1.03 & $1.06^{\mathrm{a}}$ \\
\hline--- & 60 & $1.03^{\mathrm{b}}$ & $2.35^{b}$ & 0.30 & $3.71^{b}$ & 0.62 & $0.93^{b}$ & $1.78^{b}$ & $1.33^{b}$ & 0.75 & $1.46^{\mathrm{b}}$ & 1.03 & $1.03^{\mathrm{b}}$ \\
\hline Conditioning Time SEM & --- & 0.004 & 0.007 & 0.003 & 0.009 & 0.031 & 0.002 & 0.004 & 0.005 & 0.001 & 0.004 & 0.004 & 0.004 \\
\hline \multicolumn{14}{|c|}{ Probability Values } \\
\hline Conditioning Temperature & --- & 0.0003 & $<0.0001$ & 0.0747 & $<0.0001$ & 0.7479 & $<0.0001$ & 0.0010 & $<0.0001$ & $<0.0001$ & 0.8432 & $<0.0001$ & $<0.0001$ \\
\hline Conditioning Time & --- & $<0.0001$ & $<0.0001$ & 0.1500 & $<0.0001$ & 0.2322 & $<0.0001$ & $<0.0001$ & $<0.0001$ & 0.4425 & 0.0003 & 0.1261 & $<0.0001$ \\
\hline $\begin{array}{l}\text { Conditioning Temperature } \\
\text { by Conditioning Time }\end{array}$ & --- & 0.0007 & $<0.0001$ & 0.1398 & $<0.0001$ & 0.8204 & $<0.0001$ & $<0.0001$ & $<0.0001$ & $<0.0001$ & 0.0002 & $<0.0001$ & $<0.0001$ \\
\hline
\end{tabular}

${ }^{\mathrm{a}-\mathrm{e}}$ Means within a column not sharing a common superscript differ significantly $(\mathrm{P}<0.05)$.

${ }^{1}$ SEM: Pooled Standard Error of the Mean. 
Figure 1. Interaction of Digestible Lysine Concentration.

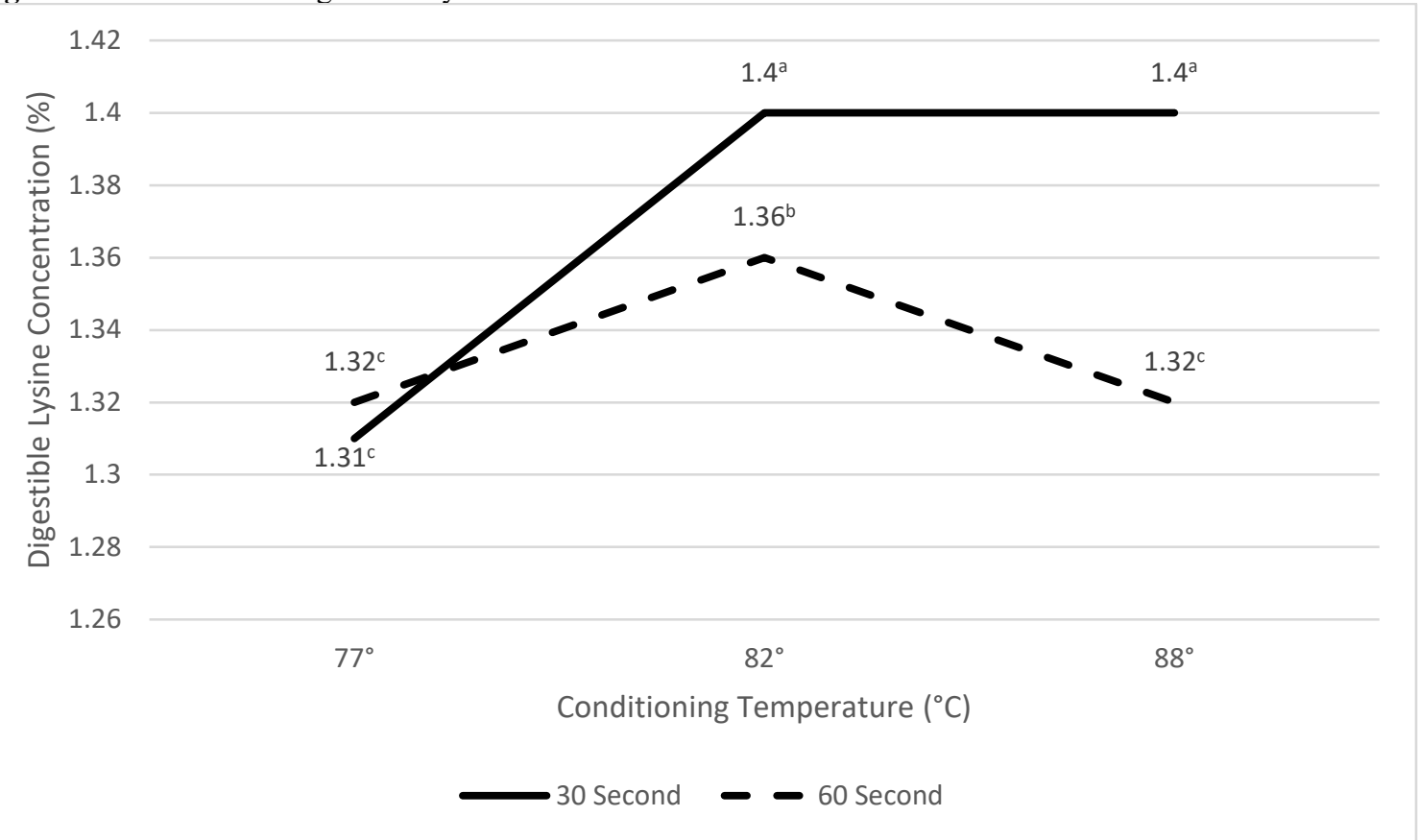

a-c Means within a column not sharing a common superscript differ significantly $(\mathrm{P}<0.05)$.

Figure 2. Interaction of Digestible Methionine Concentration.

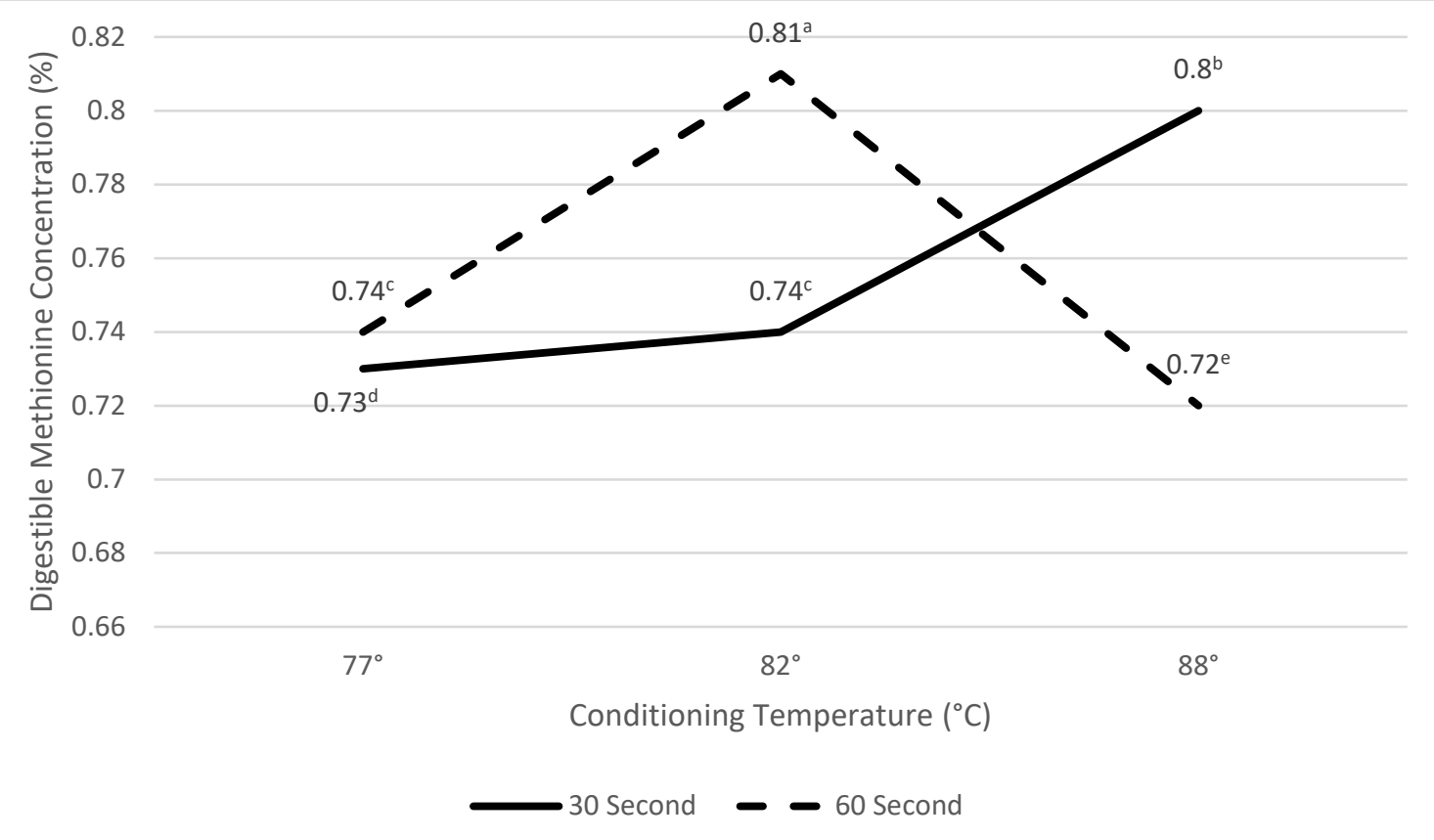

a-e Means within a column not sharing a common superscript differ significantly $(\mathrm{P}<0.05)$ 
Figure 3. Interaction of Digestible Threonine Concentration.

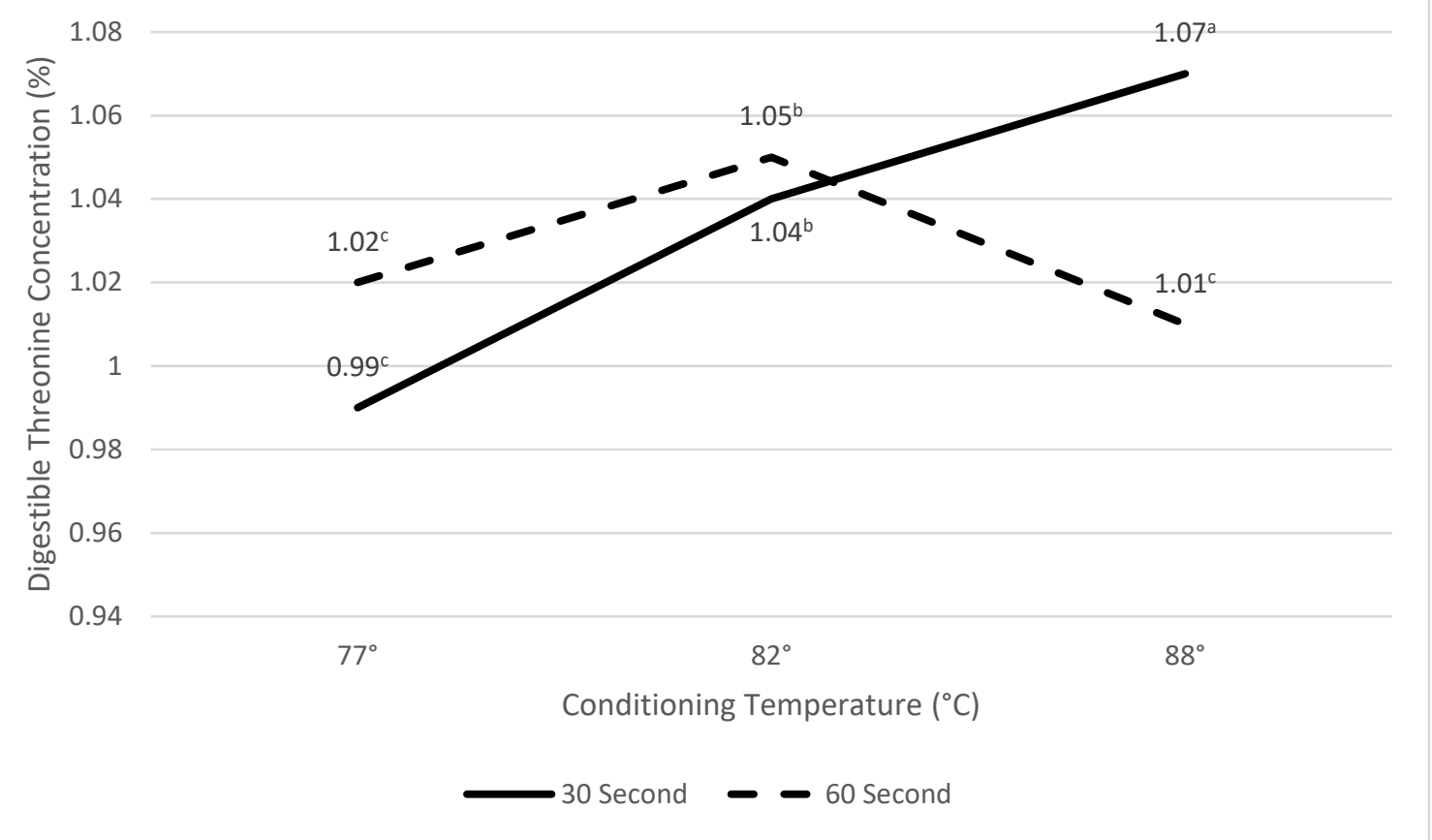

a-c Means within a column not sharing a common superscript differ significantly $(\mathrm{P}<0.05)$. 


\section{CIRRICULUM VITAE}

\section{Timothy P. Boltz}

28 Drake Road, Morgantown, WV $26501 \quad$ tpb0015@mix.wvu.edu $\quad$ (307) 286-6989

\section{EDUCATION}

Degree Obtained: Associate of Science Degree, Agriculture; May 2015

University Attended: Laramie Country Community College

Undergraduate GPA: 3.913

Degree Obtained: Bachelor of Science, Animal Science; May 2017

University Attended: Colorado State University

Undergraduate GPA: 3.967

Expected Degree: Master of Science, Animal and Food Science

Expected Graduation Date: May 2019

University Attended: West Virginia University

Current GPA: 3.875

\section{EDUCATION HONORS/AWARDS}

\section{Scholarships/Grants Received}

- Presidential Scholarship: 2013-2015

- Janie Smith Memorial 4-H Scholarship: 2013

\section{Awards and Honors}

- Graduation with Honors (Summa Cum Laude): Spring 2017

- College of Agricultural Sciences Dean's List: Fall 2015-Spring 2017

- Obtained Eagle Scout Rank from Troop 221: 2013 


\title{
PUBLICATIONS
}

\section{First Author Publications}

T. P. Boltz, J. W. Boney, C. Shen, J. Jaczynski and J. S. Moritz. The Effect of Standard Pelleting and More Thermally Aggressive Pelleting utilizing a Hygieniser on Feed Manufacture and Reduction of Enterococcus faecium, a Salmonella Surrogate. (In Preparation)

T. P. Boltz, N. E. Ward, V. E. Ayres, A. E. Lamp and J. S. Moritz. The Effect of Varying Steam Conditioning Temperature and Time on Pellet Manufacture Variables, Digestible Amino Acid Concentration, and Feed Enzyme Recovery. (In Preparation)

\begin{abstract}
s
T. P. Boltz, J.W. Boney, and J.S. Moritz. 2018. Feed manufacture and Salmonella surrogate mitigation differences between standard pelleting and more thermally aggressive pelleting utilizing a hygieniser. Poult. Sci. (Accepted Abstract (161)).
\end{abstract}

T. P. Boltz, N. E. Ward, V. E. Ayres, A. E. Lamp and J. S. Moritz. The Effect of Varying Steam Conditioning Temperature and Time on Pellet Manufacture Variables, Digestible Amino Acid Concentration, and Feed Enzyme Recovery. (In Preparation)

K. Harding, A. E. Lamp, T. P. Boltz, V. Ayres, and J. S. Moritz. The Effect of Pelleting Diets Composed of Large Particle Corn using Standard Conditioning and More Thermally Aggressive Conditioning Utilizing a Hygieniser. (In Preparation)

\section{RESEARCH EXPERIENCE}

\section{National Meeting Paper Presentations}

- 2018 Poultry Science Association Annual Meeting (San Antonio, TX) (Graduate Student)

- "Feed manufacture and Salmonella surrogate mitigation differences between

Graduate Teaching Assistant standard pelleting and more thermally aggressive pelleting utilizing a hygieniser."

- Teaching Assistant for Companion Animal Science Class: Fall 2018

- Assisted Dr. Joseph Moritz instructing classes, graded assignments, and lectured on reptile and amphibian management/nutrition.

\section{Graduate Research Assistant}

- WVU Pilot Feed Mill Manager: Fall 2017-Present

- Led multiple pelleting trials with United Animal Health to test thermostability of enzyme premixes: May, August, December 2018

- Led a contract study with Huvepharma to test a novel pellet binder: May 2018 
- Led a pelleting trial with DSM Nutritional Products, Inc. utilizing a phytase and murimadase product added to diets to determine thermostability: April 2018

- Lead a pelleting trial to determine Salmonella mitigation potential of new hygieniser: March 2018

- Attended the Poultry Science Association's Annual Meeting: 2018

- San Antonio, TX (2018)

- Assisted with a traveling backyard poultry demonstration in various locations throughout the state of West Virginia: Fall 2017-Present.

- Assisted with numerous West Virginia University Animal Science Farm tours: Fall 2017present

- $\quad$ Assisted with the Poultry Festival: 2018

o Moorefield, WV

- Assisted with conducting an annual poultry judging competition

- Assisted with the West Virginia State FFA Poultry CDE Competition: 2017, 2018

- Helped organized the competitions

- Davis College Welcome Back BBQ: 2017, 2018

○ Assisted Dr. Joseph Moritz preparing and delivering food

- Feed mill management

- Ingredient sourcing and ordering

- Efficient in Microsoft Word, Microsoft Excel, and Microsoft PowerPoint

- California Pellet Mill operation

- Poultry processing

- Cecectomy surgery

- Precision-feeding

- Tibia extraction

- Ileum extraction

- Experience using SAS software

- Pellet Quality Analysis (Pfost Tumbling Box and New Holman Pellet Tester)

- Dry matter analysis

- Kjeldahl analysis

- Freezer dryer operation

- Salmonella surrogate inoculum preparation

- Sample preparation for analysis of Salmonella surrogate in poultry feed

- Vacuum filtration

- Agar plate preparation 